D) Check for updates

Cite this: Dalton Trans., 2020, 49 12025

Received 9th July 2020,

Accepted 11th August 2020

DOI: $10.1039 / \mathrm{d} 0 \mathrm{dt} 02434 a$

rsc.li/dalton

\title{
Bis-cyclometallated Ir(III) complexes containing 2-(1H-pyrazol-3-yl)pyridine ligands; influence of substituents and cyclometallating ligands on response to changes in $\mathrm{pH} \dagger$
}

\begin{abstract}
Noreldin S. Y. Abdolla, (D) † David L. Davies, (D)* Mark P. Lowe and Kuldip Singh
Bis-cyclometallated Ir(III) complexes containing 2-(1H-pyrazol-3-yl)pyridine ligands have been synthesised. Their absorption is almost unchanged with changes in $\mathrm{pH}$ however the emission intensities vary by a factor of up to three and the complexes have emission $p K_{a} s$ in the range 8.0 to 10.0. Substituents on the pyrazole have only a minor effect on the emission $p K_{a}$. Surprisingly the complexes with phenylpyrazole cyclometallated ligands $3 \mathrm{aL}_{1-3}$ showed an intensity decrease with increasing $\mathrm{pH}$ (switch off) whilst the corresponding phenylpyridine ones $3 \mathrm{CL}_{1-3}$ showed an increase in emission intensity with increasing $\mathrm{pH}$. Putting electron-withdrawing $\mathrm{CF}_{3}$ substituents on the cyclometallating phenyls reduced the $\mathrm{p}_{\mathrm{a}}$ of the complexes to 6.8-7.8, thereby extending the useful $\mathrm{p} K_{\mathrm{a}}$ range; however, in general it tended to reduce the magnitude of the change in emission intensity. Surprisingly the $\mathrm{CF}_{3}$-substituted complexes also showed a complete reversal in the direction of the intensity change when compared to their respective unsubstituted congeners.
\end{abstract}

\section{Introduction}

Luminescent $\mathrm{pH}$ sensors have attracted significant interest for measuring $\mathrm{pH}$ in biological environments due to their excellent sensitivity, minimal damage to living samples, specificity, the availability of a wide range of indicator dyes, high signalto-noise ratios and the ability to continuously monitor rapid pH changes. Furthermore, fluorescence microscopic imaging allows mapping of the spatial and temporal distribution of $\mathrm{H}^{+}$ within living cells. ${ }^{1}$ To date, $\mathrm{pH}$ sensors have primarily focussed on organic molecules; however, transition metal and rare earth metal complexes have also been studied. ${ }^{2}$ Transition metal complexes are attractive as possible $\mathrm{pH}$ sensors due to significant Stokes shifts for easy separation of excitation and emission, tuneable emission wavelength, and relatively long emission lifetimes compared to organic molecules allowing for possible luminescent lifetime imaging of $\mathrm{pH}^{3}$ Several

School of Chemistry, University of Leicester, Leicester LE1 7RH, Libya. E-mail:dld3@le.ac.uk

$\dagger$ Electronic supplementary information (ESI) available: Crystallographic data (CIF), extra molecular structures, absorption and emission spectra and $\mathrm{pH}$ titrations, NMR spectra. CCDC 2014697-2014704. For ESI and crystallographic data in CIF or other electronic format see DOI: 10.1039/d0dt02434a

\$Current address, Chemistry Department, Faculty of Science, Omar Al-Mukhtar University, Torbruk, Libya. luminescent complexes of the platinum group metal ions have been used as $\mathrm{pH}$ sensors, notably $\mathrm{Ru}(\mathrm{II}),{ }^{4} \mathrm{Re}(\mathrm{I}),{ }^{5}$ and $\mathrm{Pt}(\mathrm{II}) .{ }^{1 a, 6}$

Iridium complexes have also been used for $\mathrm{pH}$ sensing. An early example by Licini and Williams used Ir bis-terpyridine complexes, (Fig. 1) containing either pyridyl or phenol substituents as the $\mathrm{pH}$ responsive groups which exhibit changes in lifetime and intensity with changing $\mathrm{pH}^{7}{ }^{7}$ The $\mathrm{p} K_{\mathrm{a}} \mathrm{s}$ of the complexes ranged from $4.1\left(c f\right.$. , pyridinium $\left.\mathrm{p} K_{\mathrm{a}}=5.25\right)$ to 8.1 ( $c f$. , phenol $\mathrm{p} K_{\mathrm{a}}=10.0$ ), in both cases the cationic electron-withdrawing metal terpyridyl unit reduces the basicity of the pendant group, pyridine or phenol, respectively.

The coordination of a functionalised ligand to a metal tends to lead to a reduction in electron density due to electron donation to the metal and hence should lead to a lowering of the $\mathrm{p} K_{\mathrm{a}}$ for the ligand in the ground state. However, it should

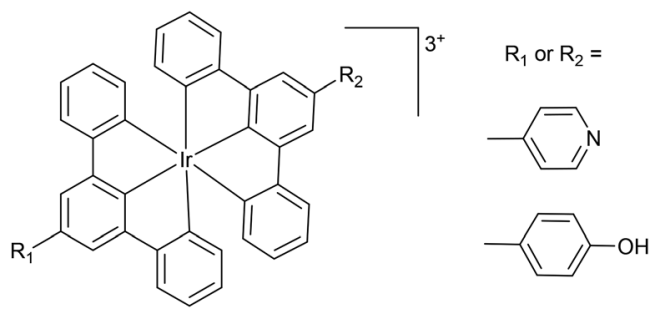

Fig. 1 Early examples of $\mathrm{pH}$ sensitive luminescent Ir(III) complexes. ${ }^{7}$ 
be noted that it is harder to predict the outcome for an excited state.

In the last 20 years there has been huge interest in the use of cyclometallated $\operatorname{Ir}(\mathrm{III})$ complexes of general formula [Ir $\left.\left(\mathrm{C}^{\wedge} \mathrm{N}\right)_{2}\left(\mathrm{X}^{\wedge} \mathrm{Y}\right)\right]^{n+}\left(\mathrm{C}^{\wedge} \mathrm{N}=\mathrm{a}\right.$ cyclometallated ligand, $\mathrm{X}^{\wedge} \mathrm{Y}=\mathrm{a}$ neutral or anionic bidentate ligand $n=0,1$; Fig. 2 structure A) which have interesting photophysical properties and have found applications particularly in OLEDS, sensors and as labels for biological imaging. ${ }^{8}$ A comparatively small number show $\mathrm{pH}$ responsive emission, changing wavelength and/or intensity of emission. A number of different $\mathrm{pH}$ responsive ligands have been used, and some of these are shown in Fig. 2. The $\mathrm{pH}$ responsive group can be on the cyclometallating $\left(\mathrm{C}^{\wedge} \mathrm{N}\right)$ ligands or on the ancillary $\left(\mathrm{X}^{\wedge} \mathrm{Y}\right)$ ligand. For example, tris-cyclometallated complexes with protonatable pyridyl ${ }^{9}$ or amine $^{10}$ substituents (B or C Fig. 2) have been reported. Biscyclometallated complexes with ligands $\mathbf{D}$ were non-emissive at low $\mathrm{pH} 2-5$ but gave red emission at higher $\mathrm{pH}$ which was ascribed to deprotonation of the carboxylic acid groups. ${ }^{11}$ The $\mathrm{p} K_{\mathrm{a}}$ value was approximately 7.0, suggesting that the probe may useful for monitoring $\mathrm{pH}$ in biological systems.

Several proton responsive $\mathrm{N}^{\wedge} \mathrm{N}$ ligands have been used as the ancillary $\mathrm{X}^{\wedge} \mathrm{Y}$ ligand in bis-cyclometallated complexes (Fig. 2 E-H). For example, functionalised bipyridine ligands, with morpholine $\mathbf{E}^{12}$ or carboxylic acid substituents $\mathbf{F}^{13}$ Several groups have investigated complexes with imidazole or benzimidazole containing ligands e.g. G. ${ }^{14}$ Similar carbolinecontaining ligands $\mathbf{H}$ gave $\mathrm{pH}$-sensitive iridium(III) complexes used in lysosome targeted photodynamic therapy (PDT). ${ }^{15}$ The complexes were more emissive at low $\mathrm{pH}$ with $\mathrm{p} K_{\mathrm{a}}$ values between 3.6 and 4.4.

Although, imidazole-based ligands have been investigated, pyrazole ligands with an $\mathrm{NH}$ moiety have been much less studied. Lam et al. studied a Re-carbonyl complex containing a bidentate pyrazolyl-pyridine. ${ }^{5 b}$ Cyclometallated Pt complexes with tridentate pyrazolyl-containing ligands have also been studied which show $\mathrm{pH}$ dependent emission some of which have been in used in cell imaging. ${ }^{6 b, 16}$ Hence, we have investigated Ir(III) bis-cyclometallated complexes with 2-(1H-pyrazol-3yl)pyridine ligands. 2-(1H-pyrazol-3-yl)pyridine itself has a $\mathrm{p} K_{\mathrm{a}}$ of 11.6. ${ }^{17}$ We have investigated the effect of the nature of the cyclometallated ligands, phenylpyrazole and phenylpyridine respectively and ones with an electron-withdrawing $\mathrm{CF}_{3}$ substituent, and of substituents on the pyrazole.

\section{Results and discussion}

\section{Synthesis}

The bis-cyclometallated dimers 1a-d (Chart 1) were prepared by a literature method ${ }^{18}$ and the data are consistent with those published. ${ }^{18,19}$ The syntheses of cationic complexes $\mathbf{2} \mathbf{a H L}_{\mathbf{1 - 3}}$ are outlined in Scheme 1. The dimer 1a was reacted with the relevant 2-(1H-pyrazol-3-yl)pyridine $\left(\mathbf{H L}_{\mathbf{1 - 3}}\right)$ in the presence of $\mathrm{KPF}_{6}$ in methanol at $60{ }^{\circ} \mathrm{C}$ under microwave irradiation for 20-40 minutes (see Experimental section). After work up, complexes $\mathbf{2} \mathbf{a H L}_{\mathbf{1 - 3}}$ were formed in good to excellent yields.

${ }^{1} \mathrm{H}$ and ${ }^{13} \mathrm{C}$ NMR spectra for all the complexes were assigned using two-dimensional NMR experiments such as TOCSY, COSY, NOESY, and HMQC. The coordination of the $\mathrm{N}^{\wedge} \mathrm{N}$ ligand removes the $C_{2}$-symmetry of the dimers, causing the two $\mathrm{C}^{\wedge} \mathrm{N}$ ligands to become inequivalent and therefore doubling the number of peaks for the cyclometallated ligands. The ${ }^{1} \mathrm{H}$ and ${ }^{13} \mathrm{C}$ NMR spectra of $\mathbf{2 a H L}_{1-3}$ are similar to each other therefore, only the assignment of complex $\mathbf{2} \mathbf{a H L}_{\mathbf{1}}$ is discussed in detail.

The ${ }^{1} \mathrm{H}$ NMR spectrum of complex $2 \mathbf{a H L}_{\mathbf{1}}$ contains twentyone aromatic environments. There are two doublets of doub-

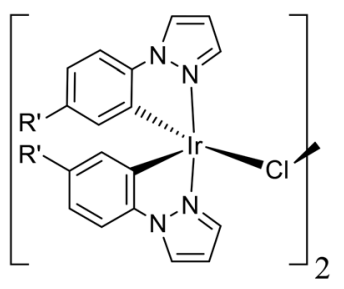

1a $\mathrm{R}^{\prime}=\mathrm{H}$

1b $\mathrm{R}^{\prime}=\mathrm{CF}_{3}$

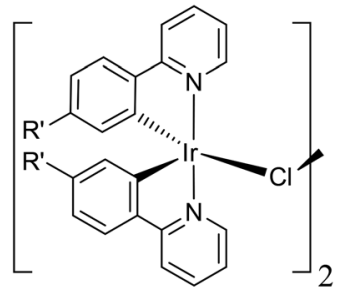

$1 c \mathrm{R}^{\prime}=\mathrm{H}$

1d $\mathrm{R}^{\prime}=\mathrm{CF}_{3}$
Chart 1 Iridium dimers used.

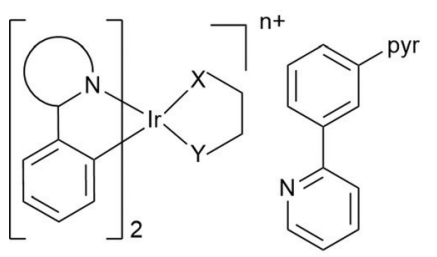

A<smiles>[R]c1cccc(-c2nccc3ccccc23)c1</smiles><smiles>[R]N=[N+]=CCNC1=NCCN1</smiles>

C<smiles>O=C(O)c1cc(-c2ccc(N(c3ccccc3)c3ccccc3)cc2)nc2ccccc12</smiles>

D

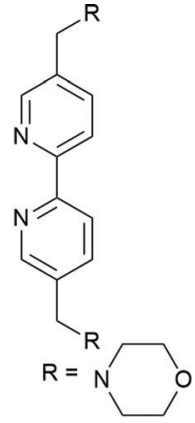

E<smiles>Cc1ccnc(-c2cc(C(=O)O)ccn2)c1</smiles>

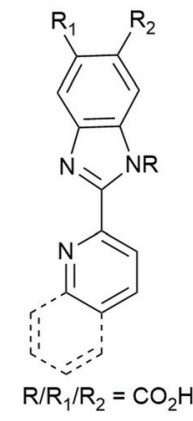

G

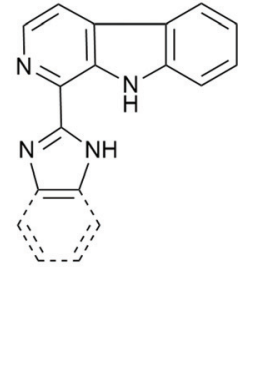

H

Fig. 2 Examples of $\mathrm{pH}$ responsive cyclometallating ligands ( $\mathrm{B}$ to $\mathrm{D}$ ) or ancillary ligands ligands (E to $\mathrm{H}$ ) used in bis- or tris-cyclometallated Ir complexes. 


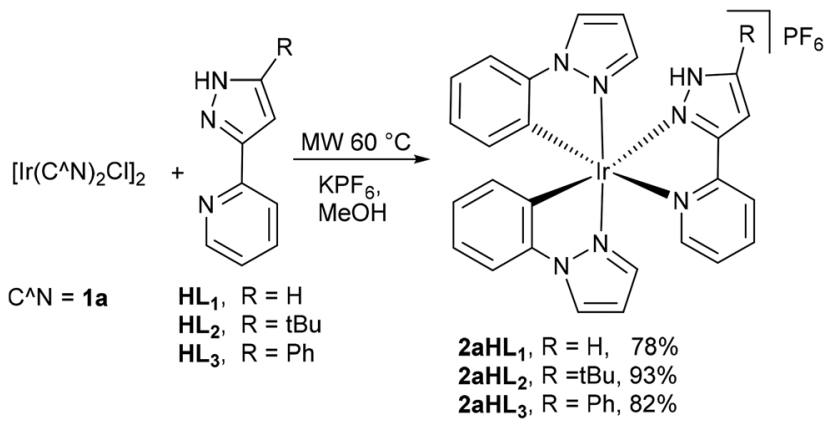

Scheme 1 Preparation of cationic bis-cyclometallated phenylpyrazole complexes.

lets at $\delta 6.30$ and 6.32 , characteristic of cyclometallated phenyl protons which are shifted to high field due to ring current effects. ${ }^{20}$ This then allows assignment of the signals for the phenyl and pyrazole rings of the $\mathrm{C}^{\wedge} \mathrm{N}$ ligands using the TOCSY and NOESY spectra (Fig. S1 and $2 \dagger$ ). Likewise, the protons of the pyrazole of the $\mathrm{N}^{\wedge} \mathrm{N}$ ligand are easily identified in the TOCSY spectrum as doublets at $\delta 7.83$ and $\delta 7.20$ slightly shifted downfield compared to the free ligand (by ca. $\delta 0.4$ and 0.2 , respectively) presumably due to the coordination of the $\left(\mathrm{N}^{\wedge} \mathrm{N}\right)$ ligand to the metal. The doublet at $\delta 7.20$ shows an NOE to a doublet of triplets at $c a . \delta 8.20$ which is therefore assigned as the closest pyridine proton $\left(\mathrm{H}_{\mathrm{e}}\right.$ see $\mathrm{ESI} \dagger$ for NMR labelling) and the other pyridine protons $\mathrm{H}_{\mathrm{f}-\mathrm{h}}$ are assigned from the TOCSY and COSY spectra. The protons $\mathrm{H}_{\mathrm{e}-\mathrm{g}}$ are shifted slightly downfield compared to the free ligand ( $c a . \delta 0.2$ to 0.4 ) as might be expected on coordination to the metal, however, the proton next to the $\mathrm{N}$ atom $\left(\mathrm{H}_{\mathrm{h}}\right)$ is observed at $\delta 8.01$ about $\delta$ 0.7 upfield compared to the free ligand $(\delta 8.68)$ due to ring currents from the neighbouring phenyl ring (A), as noted previously, e.g. for $\left[\operatorname{Ir}(\mathrm{R}-\mathrm{ppz})_{2}(\right.$ bipy $\left.)\right] \mathrm{PF}_{6} \cdot{ }^{18}$ Proton $\mathrm{H}_{\mathrm{h}}$ also shows an NOE to a pyrazole proton multiplet at $c a . \delta 7.07$ which is therefore assigned as $\mathrm{H}_{7 \mathrm{~B}}$. This distinguishes the two cyclometallating ligands and hence allows for assignment of all the other protons. The NH proton was not observed, probably due to exchange with $\mathrm{D}_{2} \mathrm{O}$ in the solvent $\left(\mathrm{CD}_{3} \mathrm{CN}\right)$. The ${ }^{13} \mathrm{C}$ NMR spectrum showed the expected number of signals, and were assigned using the HSQC and HMBC spectra. The high resolution mass spectrum (ASAP) shows a molecular ion with characteristic Ir isotopes pattern for the cation at $\mathrm{m} / \mathrm{z} 624.1497$ (624.1488 calculated for $\mathrm{C}_{26} \mathrm{H}_{21}{ }^{193} \mathrm{IrN}_{7}$ ).

The ${ }^{1} \mathrm{H}$ NMR spectra of $\mathbf{2} \mathbf{a H L}_{2}$ and $\mathbf{2} \mathbf{a H L}_{3}$ are similar to that of $2 \mathbf{a H L}_{\mathbf{1}}$ except for the substituent on the $\mathrm{N}^{\wedge} \mathrm{N}$ pyrazole, a singlet due to a ${ }^{t} \mathrm{Bu}$ at $\delta 1.26$ for $2 \mathrm{aHL}_{2}$ and extra signals in the aromatic region for $2 \mathbf{a H L}_{3}$. For $2 \mathbf{a H L}_{3}$ a downfield singlet at $\delta$ 12.01 was assigned to the $\mathrm{NH}$ proton. The ${ }^{13} \mathrm{C}$ NMR spectra showed the expected number of signals and both complexes showed an ion corresponding to the cationic complex in their high resolution (ASAP) mass spectra.

The neutral complexes $3 \mathbf{a L}_{1-3}$ corresponding to loss of a proton from $\mathbf{2} \mathbf{H L}_{1-3}$ were synthesised in good yields by reaction of dimer $\mathbf{1 a}$ with ligands $\mathbf{H L}_{\mathbf{1}}-\mathbf{H L}_{3}$ and $\mathrm{NaOMe}$ in a

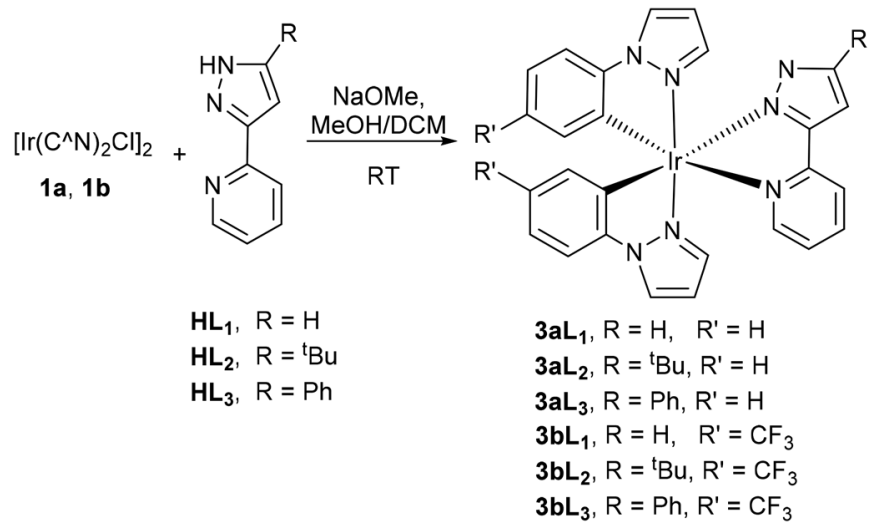

Scheme 2 Preparation of neutral bis-cyclometallated complexes of phenyl pyrazole.

mixture of DCM/methanol (2:1) (Scheme 2). Additionally, a $\mathrm{CF}_{3}$ substituted dimer $\mathbf{1 b}$ was also used to investigate the effect of an electron withdrawing substituent on the cyclometallating ligand, providing complexes $\mathbf{3} \mathbf{b L}_{\mathbf{1 - 3}}$.

The ${ }^{1} \mathrm{H}$ and ${ }^{13} \mathrm{C}$ NMR spectra of $\mathbf{3 a L}_{1-3}$, are similar to those for $\mathbf{2} \mathbf{A H L}_{1-3}$, respectively, and assignments have been made on this basis. As expected, in the majority of cases the deprotonation of the ancillary ligand causes an upfield shift of the protons of the $\mathrm{N}^{\wedge} \mathrm{N}$ ligand in the ${ }^{1} \mathrm{H}$ NMR spectra compared to their corresponding cationic complexes. For example, for $\mathbf{3 a L}_{\mathbf{1}}$ the pyrazole protons $\mathrm{H}_{\mathrm{a}, \mathrm{b}}$ are observed as mutually coupled doublets at $\delta 7.47$ and 6.82 , respectively, upfield compared to the corresponding signals in the cationic complex $2 \mathbf{a H L}_{\mathbf{1}}(\delta$ 7.83 and 7.20 respectively) consistent with deprotonation of the pyrazole. Unusually, for $\mathbf{3 a L}_{\mathbf{1}}$ the most upfield resonance in the aromatic region is a pyrazole proton not a cyclometallated phenyl. The spectra of the $\mathrm{CF}_{3}$-substituted complexes $\mathbf{3} \mathbf{b L}_{\mathbf{1 - 3}}$ are similar to those of the unsubstituted complex but with two fewer resonances in the aromatic region. The ${ }^{19} \mathrm{~F}$ NMR spectra of $\mathbf{3} \mathbf{b L}_{\mathbf{1 - 3}}$ exhibit two singlets at about $-60 \mathrm{ppm}$ corresponding to two different $\mathrm{CF}_{3}$ groups. All of the neutral complexes show ions due to $[\mathrm{M}+\mathrm{H}]^{+}$in their high-resolution mass spectra.

The corresponding complexes containing cyclometallated phenylpyridine ligands in place of phenylpyrazole were prepared by analogous procedures to give cationic complexes $\mathbf{2} \mathbf{C H L}_{1-3}$ and neutral complexes $\mathbf{3} \mathbf{C L}_{1-3}$ and $\mathrm{CF}_{3}$-substituted complex $\mathbf{3} \mathbf{d L}_{2}$ respectively (see Chart 2 ). These were fully characterised by ${ }^{1} \mathrm{H}$ and ${ }^{13} \mathrm{C}$ NMR spectroscopy and highresolution mass spectra.

The ${ }^{1} \mathrm{H}$ NMR spectra of $\mathbf{2} \mathbf{c H L}_{1-3}$ show the cyclometallated phenyl protons as the most upfield aromatic signals, between $\delta 6.23$, and 6.35. The pyridine proton next to nitrogen for both the cyclometallating ligands and the $\mathrm{N}^{\wedge} \mathrm{N}$ ligand are all influenced by ring currents from the other ligands and hence are shifted upfield compared to the free ligands, being observed between $\delta 7.9$ and 7.5. The ${ }^{1} \mathrm{H}$ NMR spectra for neutral complexes $3 \mathbf{C L}_{1-3}$ show the cyclometallated phenyl protons between $\delta 6.23$ and 6.39 within $0.1 \mathrm{ppm}$ of the related cationic 


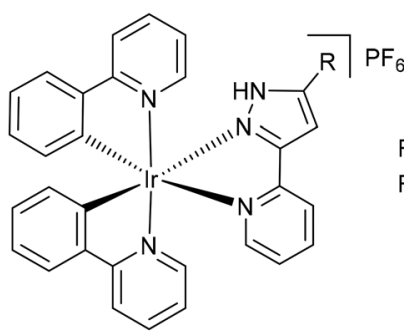

$2 \mathrm{cHL}_{1}, \mathrm{R}=\mathrm{H}, \quad \mathrm{R}^{\prime}=\mathrm{H}$

$2 \mathrm{cHL}_{2}, \mathrm{R}={ }^{\mathrm{t}} \mathrm{Bu}, \mathrm{R}^{\prime}=\mathrm{H}$

$2 \mathrm{CHL}_{3}, \mathrm{R}=\mathrm{Ph}, \mathrm{R}^{\prime}=\mathrm{H}$

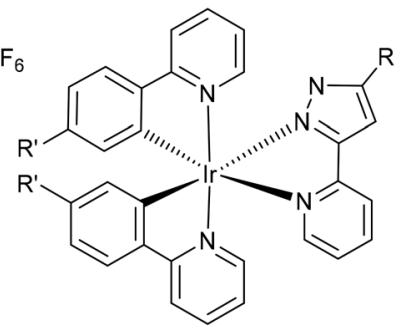

$3 c L_{1}, R=H, \quad R^{\prime}=H$

$3 \mathrm{cL}_{2}, \mathrm{R}={ }^{\mathrm{t}} \mathrm{Bu}, \mathrm{R}$ ' $=\mathrm{H}$

$3 \mathrm{cL}_{3}, \mathrm{R}=\mathrm{Ph}, \mathrm{R}^{\prime}=\mathrm{H}$

$3 \mathrm{dL}_{2}, \mathrm{R}={ }^{\mathrm{t}} \mathrm{Bu}, \mathrm{R}^{\prime}=\mathrm{CF}_{3}$

Chart 2 Labelling of bis-cyclometallated complexes of phenylpyridine.

complexes. As for $3 \mathbf{a L}_{1-3}$ deprotonation of the pyrazole $\mathrm{NH}$ proton $\mathbf{3} \mathbf{C L}_{\mathbf{1 - 3}}$ leads to an approximately $0.5 \mathrm{ppm}$ upfield shift for pyrazole proton $\mathrm{H}_{\mathrm{b}}$. All the other protons are within $0.2-0.3 \mathrm{ppm}$ of the signals in the corresponding cationic complexes $\mathbf{2}^{\mathbf{C H L}_{1-3}}$. The ${ }^{13} \mathrm{C}$ NMR spectra show the expected number of signals for $2 \mathbf{c H L}_{1-3}$. The ${ }^{1} \mathrm{H}$ and ${ }^{13} \mathrm{C}$ NMR spectra of $\mathbf{3} \mathbf{d} \mathbf{L}_{2}$ are similar to $\mathbf{3} \mathbf{c} \mathbf{L}_{2}$, except the signals for one proton on each the phenyl rings of the $\mathrm{C}^{\wedge} \mathrm{N}$ ligands have been replaced by a $\mathrm{CF}_{3}$ group, as confirmed by ${ }^{19} \mathrm{~F}$ NMR spectroscopy. The high-resolution mass spectra (ASAP) each show a molecular ion for the cations $\mathbf{2} \mathrm{CHL}_{1-3}$ and the protonated molecular ions for $3 \mathbf{C L}_{1-3}$ and $\mathbf{3} \mathbf{d L}_{1-3}$.

\section{X-ray crystallography}

The cationic complexes were relatively easy to crystallise as their $\mathrm{PF}_{6}$ salts, hence complexes $2 \mathbf{a H L}_{1-3}$ and $\mathbf{2} \mathbf{C H L}_{1-3}$ were characterised by X-ray crystallography. In addition, two of the neutral molecules $\mathbf{3} \mathbf{a L}_{2}$ and $\mathbf{3} \mathbf{c} \mathbf{L}_{3}$ were also characterised by X-ray crystallography. As examples the structures of two cationic/neutral pairs $\mathbf{2} \mathbf{a H L}_{2}$ and $\mathbf{3} \mathbf{a L}_{2}$, and $\mathbf{2} \mathbf{c H L}_{3}$ and $\mathbf{3} \mathbf{c L}_{3}$ are shown in Fig. 3 and 4 respectively, the remaining structures are in Fig. S3 and S4 $\uparrow$ with selected bond lengths and angles in Tables $\mathrm{S} 1$ and $\mathrm{S} 2 . \dagger$

All the crystal structures show the expected distorted octahedral coordination geometry with cis metallated carbons and trans nitrogen atoms. The chelate bite angles for the cyclometallated ligands are all about $80^{\circ}$, and about $75^{\circ}$ for the $\mathrm{N}^{\wedge} \mathrm{N}$

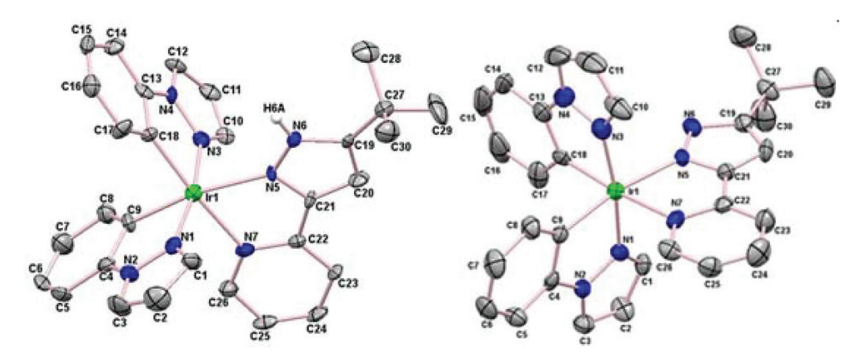

Fig. 3 Left, structure of the cation of $2 \mathrm{aHL}_{2}$ and right the structure of $3 \mathrm{~L}_{2}$ showing $50 \%$ ellipsoids. All hydrogen atoms (except $\mathrm{NH}$ ) have been omitted for clarity.

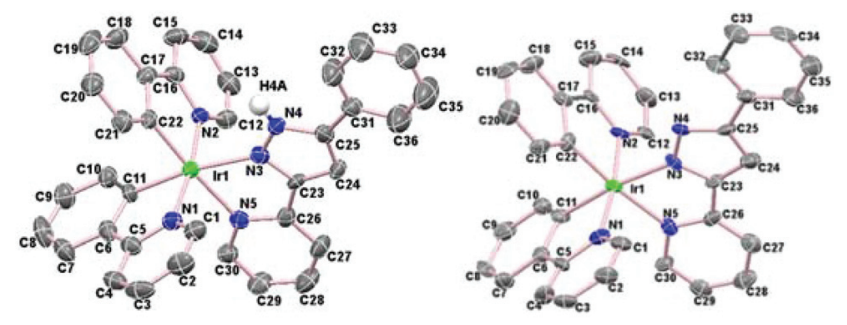

Fig. 4 Left, structure of the cation of $2 \mathrm{cHL}_{3}$ and right the structure of $3 \mathrm{CL}_{3}$ showing $50 \%$ ellipsoids. All hydrogen atoms (except $\mathrm{NH}$ ) have been omitted for clarity.

ligands. The Ir- $\mathrm{N}$ bond lengths to the $\mathrm{N}^{\wedge} \mathrm{N}$ ligand are longer than those to the cyclometallating ligands, due to the former being trans to the $\mathrm{C}$ atoms, as observed previously. ${ }^{21}$ For example, for complex $2 \mathrm{aHL}_{1}$, [Ir(1)-N(5), 2.116(7) and $\operatorname{Ir}(1)-\mathrm{N}$ (7), 2.148(6) $\AA$ ] are longer than [Ir(1)-N(1), 2.036(7), and $\operatorname{Ir}(1)-$ $\mathrm{N}(3), 2.031(6) \AA]$ similar trends are seen for complexes $2 \mathbf{a H L}_{2-3}$. The same trend in Ir-N bond lengths is also seen for the neutral complexes. The Ir-N bond distance to the anionic pyrazole of the $\mathrm{N}^{\wedge} \mathrm{N}$ ligand [2.122(6) $\AA$ in $3 \mathrm{aL}_{2}$ and 2.088(7) $\AA$ in $\left.3 \mathbf{C L}_{3}\right]$ is shorter than that in the cationic analogue [2.175(8) $\AA$ in $\mathbf{2} \mathbf{a H L}_{2}$, and 2.149(4) $\AA$ in $\mathbf{3} \mathbf{C L}_{3}$ ] though the other Ir-N and Ir-C bonds and the chelate bite angles are statistically almost the same in both pairs of complexes. The structures of $2 \mathbf{a H L}_{1-3}$ and $\mathbf{2} \mathbf{C H L}_{\mathbf{1}}$ and $\mathbf{2} \mathbf{C H L}_{3}$ show the presence of waters of crystallisation and most of the structures show hydrogen bonding from the $\mathrm{NH}$ of the protonated pyrazole to the $\mathrm{PF}_{6}$ anion or to a water molecule.

\section{Photophysical properties}

The UV-vis absorption spectra of all 16 complexes are shown in Fig. S5-S8 $\uparrow$ and the data are collated in Table S3. $\dagger$ Cationic complexes $\mathbf{2} \mathbf{a H L}_{\mathbf{1 - 3}}$, and their neutral counterparts $\mathbf{3} \mathbf{a L}_{\mathbf{1 - 3}}$ are shown in Fig. S5 $\dagger$ whilst the $\mathrm{CF}_{3}$-substituted complexes $\mathbf{3} \mathbf{b L}_{\mathbf{1 - 3}}$ are compared with their unsubstituted analogues, $\mathbf{3 a L}_{1-3}$ in Fig. S6. $\dagger$ Similarly, spectra for phenylpyridine complexes $\mathbf{2} \mathbf{C H L}_{1-3}$, and $\mathbf{3} \mathbf{C L}_{1-3}$ are in Fig. S7 $\dagger$ and $\mathbf{3} \mathbf{C L}_{2}$, is compared with $3 \mathbf{d L}_{2}$ in Fig. S8. $\dagger$ All the complexes show strong bands between 225 and $300 \mathrm{~nm}$ due to $\pi \rightarrow \pi^{*}$ transitions in addition the phenylpyridine complexes $\mathbf{2} \mathbf{C H L}_{\mathbf{1 - 3}}, \mathbf{3} \mathbf{C L}_{\mathbf{1 - 3}}$ and $\mathbf{3} \mathbf{d L}_{\mathbf{2}}$ show weak bands between 380-405 $\mathrm{nm}$ (possibly having contributions from ${ }^{1}$ MLCT transitions). Adding a $\mathrm{CF}_{3}$ substituent to the $\mathrm{C}^{\wedge} \mathrm{N}$ ligand causes only minor changes, and these are in the short wavelength region. The substituent on the $\mathrm{N}^{\wedge} \mathrm{N}$ ligand also has very little effect on the $\lambda_{\max }$. For both the phenylpyrazole and phenylpyridine complexes there are only minor differences in uv-vis spectra between the cationic and neutral species and these are in the uv region, a slight red shift (10 to $30 \mathrm{~nm}$ ) in $\lambda_{\max }$ occurring on deprotonation. Since there is no significant change $(<20 \%)$ in absorbance at any wavelength, these complexes would not be expected to be good pH sensors in their ground states.

Emission spectra of the complexes were run in MeCN in aerated solutions. Each pair of cationic and neutral complexes 
(e.g., $\mathbf{2} \mathbf{a} \mathbf{H} \mathbf{L}_{\mathbf{1}}$ and $\mathbf{3} \mathbf{a L}_{\mathbf{1}}$ ) were irradiated at the same excitation wavelength (see Fig. S9 and $10 \dagger$ for excitation spectra). The emission spectra of phenylpyrazole cationic complexes $\mathbf{2} \mathbf{a H L}_{\mathbf{1 - 3}}$ and their neutral analogues $\mathbf{3} \mathbf{a L}_{\mathbf{1 - 3}}$ are shown in Fig. 5a whilst those of $3 \mathbf{a L}_{1-3}$ are compared with their $\mathrm{CF}_{3}$-substituted analogues $\mathbf{3} \mathbf{b L}_{\mathbf{1 - 3}}$ in Fig. $\mathbf{5 b}$ and all the associated data are reported in Table $\mathrm{S} 4 . \dagger$

All three cationic complexes $\mathbf{2} \mathbf{a H L}_{\mathbf{1 - 3}}$ show a broad emission band, each with a similar $\lambda_{\max }$ at 502, 495, and $508 \mathrm{~nm}$, respectively. Hence, the substituent on the pyrazole has only a small effect on the emission wavelength. The corresponding neutral complexes $\mathbf{3 a L}_{\mathbf{1 - 3}}$ show similar spectra with a slight blue shift in $\lambda_{\max }$ of $27 \mathrm{~nm}\left(1053 \mathrm{~cm}^{-1}\right)$ for $3 \mathbf{a L}_{\mathbf{1}}, 2 \mathrm{~nm}$ $\left(82 \mathrm{~cm}^{-1}\right)$ for $\mathbf{3} \mathbf{a L}_{2}$ and $12 \mathrm{~nm}\left(476 \mathrm{~cm}^{-1}\right)$ for $\mathbf{3} \mathbf{a L}_{3}$. The emission intensity for the neutral complexes $\mathbf{3} \mathbf{a L}_{\mathbf{1 - 3}}$ are all reduced by about $50 \%$ compared with the cationic complexes $2 \mathbf{a H L}_{\mathbf{1 - 3}}$. Hence, these complexes have potential as luminescent $\mathrm{pH}$ sensors. Neutral complexes $\mathbf{3 b L}_{\mathbf{1 - 3}}$ with an electron-withdrawing substituent $\left(\mathrm{CF}_{3}\right)$ on the phenyl ring each show a broad emission band which is blue-shifted compared to the corresponding unsubstituted complexes $\mathbf{3} \mathbf{a L}_{\mathbf{1 - 3}}$, with $\mathbf{3} \mathbf{b L}_{2}$ showing the largest shift of $35 \mathrm{~nm}\left(1550 \mathrm{~cm}^{-1}\right)$ (Fig. $5 \mathrm{~b}$ and Table $\left.\mathrm{S} 4 \dagger\right)$, respectively. A blue shift in emission by addition of electronwithdrawing groups to the $\mathrm{C}^{\wedge} \mathrm{N}$ cyclometallating ligands is a well-known phenomenon that has been ascribed to the electron-withdrawing group stabilising the HOMO. ${ }^{18,22}$

The emission spectra of the corresponding phenylpyridine complexes $\mathbf{2} \mathbf{c} \mathbf{H L}_{\mathbf{1 - 3}}$, and $\mathbf{3} \mathbf{c L}_{\mathbf{1 - 3}}$ are shown in Fig. 6 and their data are reported in Table $\mathbf{S} 4 . \dagger$ Complex $\mathbf{2} \mathbf{C H L}_{\mathbf{1}}$ shows a broad emission band $\left(\lambda_{\max } 505 \mathrm{~nm}\right)$; however, complexes $\mathbf{2} \mathbf{C H L}_{2-3}$ both show some structure in the emission band. As for the phenylpyrazole complexes, changing the $\mathbf{R}_{\mathbf{2}}$ group on the $\mathrm{N}^{\wedge} \mathrm{N}$ ligand has only a small effect on the emission wavelength. The neutral complexes $\mathbf{3} \mathbf{C L}_{\mathbf{1 - 3}}$ show similar spectra to the cationic complexes, with a broad emission band with shoulders. Surprisingly there is no significant change in emission inten-

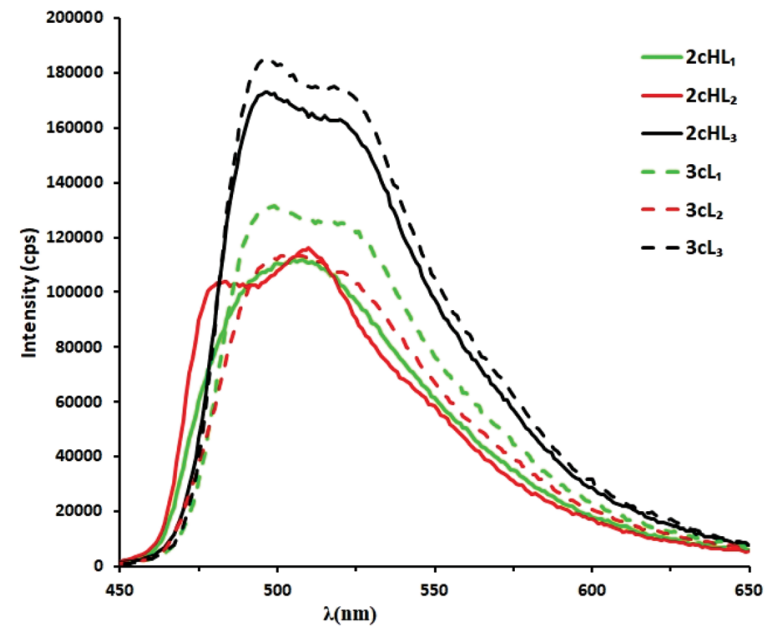

Fig. 6 Emission spectra of cationic and neutral complexes $2 \mathrm{CHL}_{1-3}(-)$ and $3 \mathrm{CL}_{1-3}(---)$, in $\mathrm{MeCN}$ at $0.02 \mathrm{mM}$ at room temperature in air; excitation at $320-325 \mathrm{~nm}$.

sity between the cationic and neutral complexes, though the neutral complexes are slightly more emissive than the cationic ones which is the opposite case to the phenylpyrazole complexes. Hence, these are not expected to be good pH sensors in their excited states (see $\mathrm{pH}$ titrations below for further discussion). The neutral $\mathrm{CF}_{3}$-substituted complex $\mathbf{3} \mathbf{d L}_{2}$ showed a $\lambda_{\max }$ at $502 \mathrm{~nm}$, a small blue shift (ca. $4 \mathrm{~nm}$ ) compared to the corresponding unsubstituted complex $\mathbf{3} \mathbf{c L}_{\mathbf{2}}$, and also shows a distinct shoulder at longer wavelength ca. $533 \mathrm{~nm}$ (Fig. S10†).

In conclusion, the UV-vis absorption spectra of all the complexes show strong bands between 200 and $300 \mathrm{~nm}$ due to $\pi \rightarrow$ $\pi^{*}$ transitions, with the phenylpyridine complexes also showing weak bands between 380-405 nm. All the complexes are emissive at room temperature in solution in air. There is no significant variation in emission wavelength upon changing the substituent on the ancillary $\mathrm{N}^{\wedge} \mathrm{N}$ ligands, and there is very
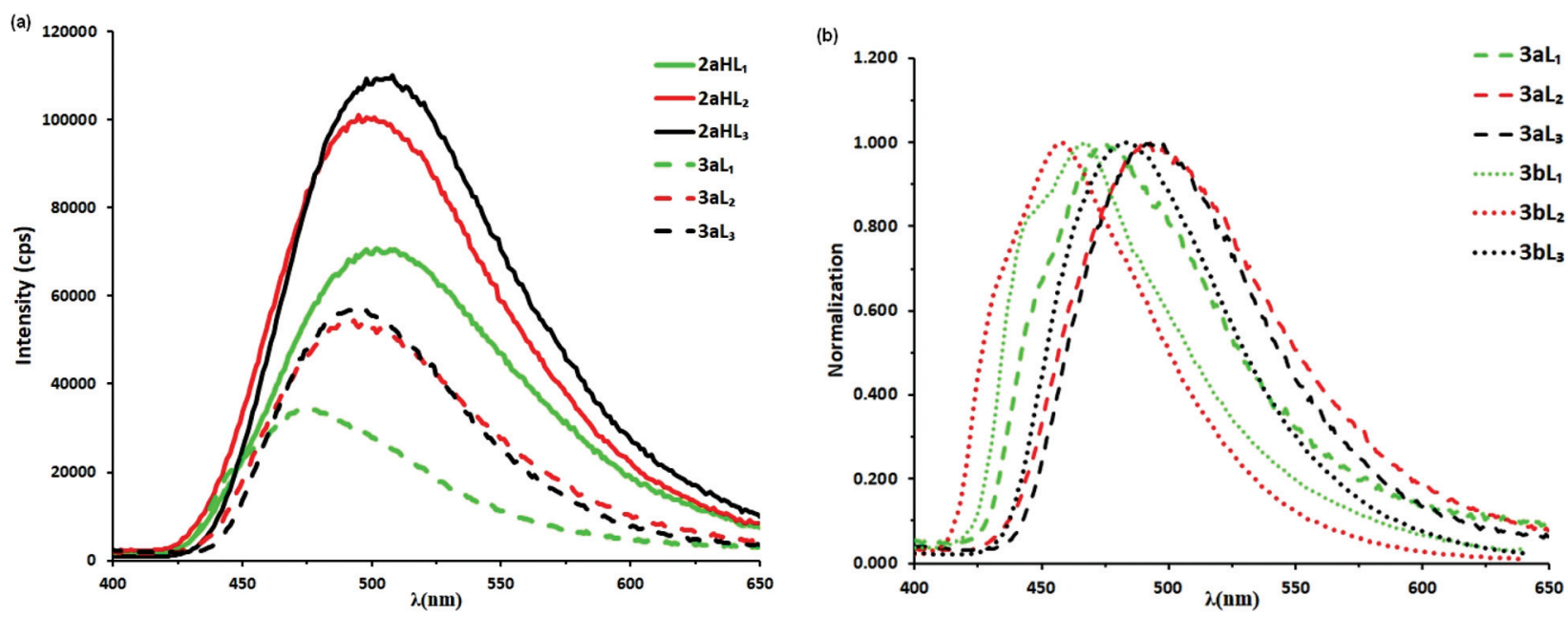

Fig. 5 Emission spectra of (a) cationic and neutral complexes $2 \mathrm{aHL}_{1-3}(-)$ and $3 \mathrm{aL}_{1-3}(---)$, (b) normalised emission spectra of neutral complexes $3 \mathrm{aL}_{1-3}(---)$ and $3 \mathrm{bL}_{1-3}(\ldots$.$) , all in \mathrm{MeCN}$ at $0.02 \mathrm{mM}$ at room temperature in air; excitation at $320-325 \mathrm{~nm}$. 
little change in $\lambda_{\max }$ on deprotonation, except for complex $\mathbf{3} \mathbf{a L}_{\mathbf{1}}$ which shows a blue shift of approximately $27 \mathrm{~nm}$. Substituting $\mathrm{H}$ with an electron-withdrawing $\mathrm{CF}_{3}$ group on the $\mathrm{C}^{\wedge} \mathrm{N}$ ligand causes a blue shift in the emission spectrum, consistent with other bis-cyclometallated Ir complexes. ${ }^{18,22}$ The effect of changing the cyclometallated ligand from phenylpyrazole to phenylpyridine is not uniform, giving a red shift in some cases and a blue shift in others. This is further complicated by the presence of shoulders on some bands.

\section{pH titrations}

To investigate their potential application as $\mathrm{pH}$ sensors, $\mathrm{pH}$ titrations of the complexes were carried out in $\mathrm{MeCN} / \mathrm{H}_{2} \mathrm{O}$ (1:9) (see Experimental for details). As expected from the studies of the isolated neutral and cationic complexes there is very little change in the uv-vis spectra with changing $\mathrm{pH}$, hence absorption spectra cannot not be used to determine ground state $\mathrm{p} K_{\mathrm{a}}$ values. The emission $\mathrm{p} K_{\mathrm{a}}$ values $^{23}$ for the complexes were determined by the change in emission intensity with $\mathrm{pH}$ over the range $\mathrm{ca} .3$ to 12.5 .

As an example, the emission $\mathrm{pH}$ titration data and $\mathrm{p} K_{\mathrm{a}}$ values of complex $\mathbf{3} \mathbf{a L}_{\mathbf{1}}$ are illustrated in Fig. 7. The emission intensity of $\mathbf{3 a L}_{\mathbf{1}}$ at $500 \mathrm{~nm}$ was relatively unchanged between $\mathrm{pH} 7.5$ and $\mathrm{pH} 3.7$, but above $\mathrm{pH} 7.5$, there was a gradual decrease in emission intensity by about a factor of two to around $\mathrm{pH}$ 10, above which the intensity remained essentially constant until $\mathrm{pH}$ 12.3. Over the full $\mathrm{pH}$ range studied, there is a small blue shift $(c a .6 \mathrm{~nm})$ in $\lambda_{\max }$. The emission $\mathrm{p} K_{\mathrm{a}}$ value was determined to be about 9.9 at the equivalent point, which is more acidic than the free 2-(1H-pyrazol-3-yl)pyridine ligand itself $\left(\mathrm{p} K_{\mathrm{a}}\right.$ 11.6). ${ }^{17}$

The emission $\mathrm{pH}$ titration spectra of complexes $3 \mathbf{a L}_{2-3}$ (Fig. S12 and $13 \dagger$ ) were similar to that of $3 \mathbf{a L}_{\mathbf{1}}$. In both complexes the emission intensity was relatively constant over the $\mathrm{pH}$ range $c a$. 4.9-7.5 but then decreased at higher $\mathrm{pH}$ by a factor of $c a .2$ for $3 \mathbf{a L}_{2}$ and $c a .1 .3$ for $3 \mathbf{a L}_{3}$. The emission $\mathrm{p} K_{\mathrm{a}}$ values of complexes $3 \mathrm{aL}_{2}$ and $3 \mathrm{aL}_{3}$ were determined to be $c a$. 10.0 and 8.9, respectively (Fig. S10 and $11 \dagger$ ), which are more acidic than the corresponding free ligands at 12.3 and 11.6, respectively. ${ }^{17}$ Hence, all three complexes $\mathbf{3 a L}_{\mathbf{1 - 3}}$ can function as $\mathrm{pH}$ sensors. However, even though the $\mathrm{p} K_{\mathrm{a}}$ of the complexes is between 1.7 and 2.7 units lower than for the free ligands, none of them are low enough to be of use as biological $\mathrm{pH}$ sensors. To lower the $\mathrm{p} K_{\mathrm{a}}$ further the complexes need to be made more acidic. Hence, complexes $\mathbf{3} \mathbf{b L}_{\mathbf{1 - 3}}$ with electronwithdrawing $\mathrm{CF}_{3}$ groups on the cyclometallating phenyls were examined.

The emission $\mathrm{pH}$ titration of complexes $\mathbf{3} \mathbf{b L}_{\mathbf{1 - 3}}$ (Fig. S14-16†) did show changes with $\mathrm{pH}$, however, for all three complexes replacing $\mathrm{H}$ with the electron-withdrawing $\mathrm{CF}_{3}$ group on the $\mathrm{C}^{\wedge} \mathrm{N}$ ligand led to a complete reversal of the shape of the $\mathrm{pH}$ titration curve. Thus, at low $\mathrm{pH}$, the complexes show low emission and at high $\mathrm{pH}$ the emission intensity is higher, which is the exact opposite of complexes $\mathbf{3 a L}_{\mathbf{1 - 3}}$. From the emission intensity changes, a $\mathrm{p} K_{\mathrm{a}}$ value of 6.8 was determined for $\mathbf{3} \mathbf{b L}_{\mathbf{1}}$ which is much smaller than the $\mathrm{p} K_{\mathrm{a}}$ (9.9) for the unsubstituted complex $3 \mathbf{a L}_{\mathbf{1}}$. The emission $\mathbf{p H}$ titration spectra of $3 \mathbf{b} \mathbf{L}_{2}$ and $3 \mathbf{b L}_{3}$ were similar to that of $\mathbf{3} \mathbf{b L}_{\mathbf{1}}$. Showing a relatively small (1.2-1.3 fold) increase in intensity with increasing $\mathrm{pH}$. The $\mathrm{p} K_{\mathrm{a}}$ values of $\mathbf{3} \mathbf{b} \mathbf{L}_{\mathbf{2}}$ and $\mathbf{3} \mathbf{b L}_{3}$ were calculated to be 7.8 and 7.5 , respectively, both lower than the $\mathrm{p} K_{\mathrm{a}}$ of the unsubstituted analogues $3 \mathbf{a L}_{2}$ and $3 \mathbf{a L}_{3}$ of 10.0 and 8.9, respectively. Hence, addition of the $\mathrm{CF}_{3}$ substituents has, as desired, lowered the $\mathrm{p} K_{\mathrm{a}}$ of the complexes by between 1.4 and 3.1 units. As noted above, the emission intensity of the $\mathrm{CF}_{3}$-substituted complexes $\mathbf{3} \mathbf{b L}_{\mathbf{1}}$ increases with increasing $\mathrm{pH}$ whilst the intensity of the unsubstituted analogues $\mathbf{3 a L}_{\mathbf{1}}$ decreases with increasing $\mathrm{pH}$. The reason for this difference is not known. In addition, the complexes, particularly $\mathbf{3} \mathbf{b L}_{2}$ and $\mathbf{3} \mathbf{b L}_{3}$ showed only a small change in emission intensity per unit change in $\mathrm{pH}$ and hence will clearly not be particularly good sensors. The

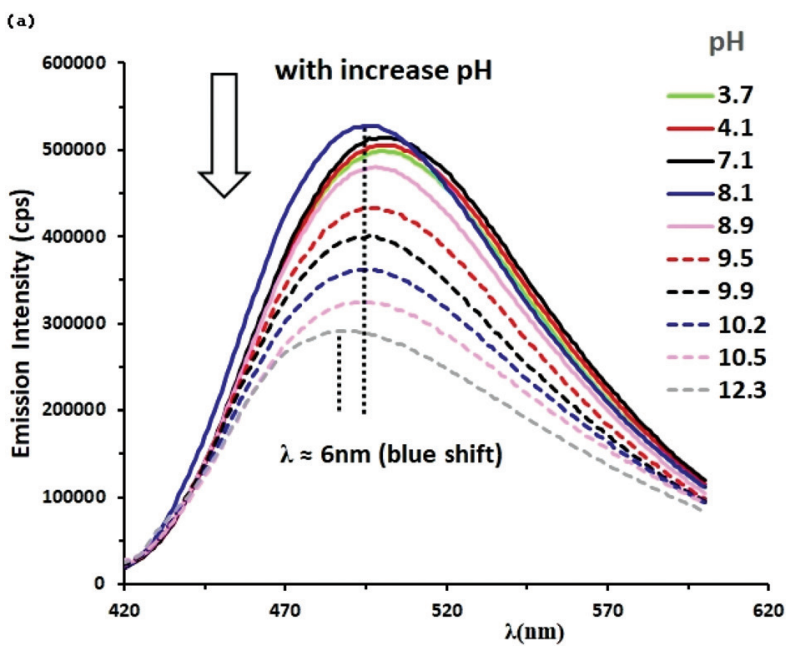

(b)

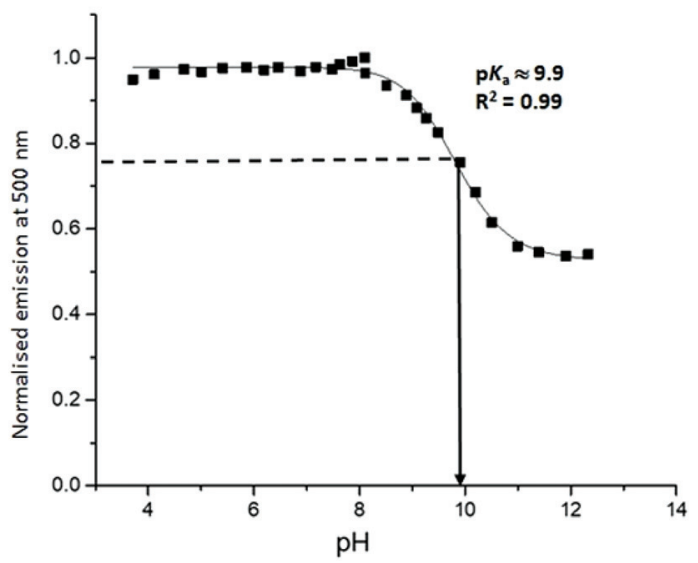

Fig. 7 (a) Selected emission spectra of complex $3 \mathrm{aL}_{1}(0.02 \mathrm{mM})$ at various $\mathrm{pH}$ values in $\mathrm{MeCN} / \mathrm{H}_{2} \mathrm{O}(1: 9)$, in air with excitation at $324 \mathrm{~nm}$. (b) Plot of normalised emission intensity of complex $3 \mathrm{aL}_{1}$ against $\mathrm{pH}$. 
(a)

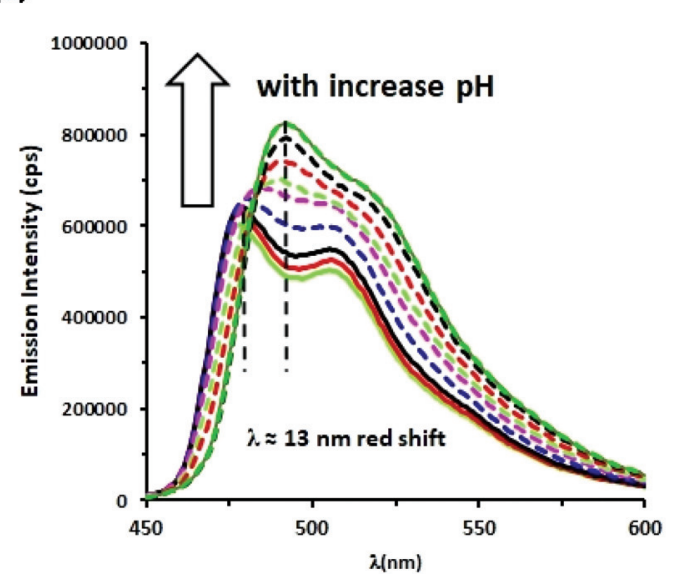

(b)

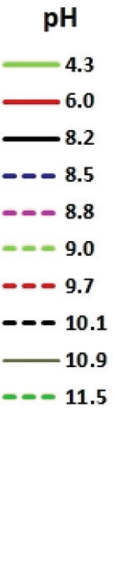

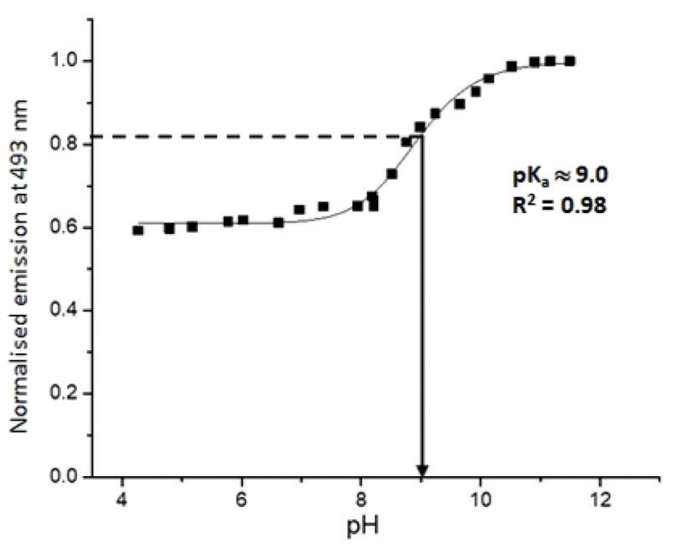

Fig. 8 (a) Selected emission spectra of complex $3 \mathrm{CL}_{1}(0.02 \mathrm{mM})$ at various $\mathrm{pH}$ values in $\mathrm{MeCN} / \mathrm{H}_{2} \mathrm{O}(1: 9)$, in air with excitation at $324 \mathrm{~nm}$. (b) Plot of normalised emission intensity of complex $3 \mathrm{cL}_{1}$ against $\mathrm{pH}$.

smaller change in intensity could be due to reduced quantum yields or may just be increased triplet character and hence more quenching by oxygen.

As mentioned above the emission spectra for cationic and neutral phenylpyridine complexes $\mathbf{2} \mathbf{C H L}_{\mathbf{1 - 3}}$ and $\mathbf{3} \mathbf{C L}_{\mathbf{1 - 3}}$ were rather similar however full $\mathrm{pH}$ titrations were still carried out. The results for $\mathbf{3} \mathbf{c} \mathbf{L}_{\mathbf{1}}$ are shown in Fig. 8 and those for $\mathbf{3} \mathbf{c L}_{2-3}$ are in Fig. S17 and 18. $\dagger$

Complex $3 \mathbf{C L}_{\mathbf{1}}$ shows two emission maxima at 479 and $505 \mathrm{~nm}$. Above $\mathrm{pH}$ 8.0, these bands start to shift to longer wavelength $\left(\lambda_{\max } 492 \mathrm{~nm}\right)$ and increase in intensity up to about $\mathrm{pH} 10.9$, above which the intensity remains essentially constant. The overall increase in intensity at $492 \mathrm{~nm}$ is by a factor of $c a$. 1.6, and the $\mathrm{p} K_{\mathrm{a}}$ was 9.0, smaller than that, 11.6, of the free ligand $\mathbf{H L}_{\mathbf{1}} \cdot{ }^{17}$ Spectral changes for $\mathbf{3} \mathbf{C L}_{2-3}$ as a function of $\mathrm{pH}$ are displayed in Fig. S17 and 18. $\dagger$ The emission intensity and wavelength of both complexes were relatively unaffected over the $\mathrm{pH}$ range from $c a$. 4 to 7.5. Further increases in $\mathrm{pH}$ led to a gradual increase in intensity by a factor of $c a .1 .8$ and 1.7 for $\mathbf{3} \mathbf{C L}_{2}$ and $\mathbf{3} \mathbf{C L}_{3}$, respectively. The $\mathrm{p} K_{\mathrm{a}}$ values of complexes $3 \mathbf{C L}_{2-3}$ are $c a .8 .0$ and 9.0, respectively, again, smaller than the ground state $\mathrm{p} K_{\mathrm{a}}$ of the free ligands $\left(12.3\right.$ for $\mathbf{H L}_{2}$ and 11.6 for $\left.\mathrm{HL}_{3}\right){ }^{17}$

Overall, the phenylpyridine complexes $\mathbf{3} \mathbf{C L}_{\mathbf{1 - 3}}$ show an increase in emission intensity with increasing $\mathrm{pH}$, which is the opposite trend to that observed for the phenylpyrazole complexes $\mathbf{3 a L}_{1-3}$ described above. This suggests that different molecular orbitals are involved in the emission from the two series of complexes. The $\mathrm{p} K_{\mathrm{a}}$ values for the phenylpyridine complexes are lower than those for the phenylpyrazole complexes for $L_{1}$ and $L_{2}$ (by approximately 1 and 2 units respectively) whilst that for $\mathrm{L}_{3}$ is about the same. However, the $\mathrm{p} K_{\mathrm{a}}$ values are still rather high for use a biological $\mathrm{pH}$ sensors hence the $\mathrm{CF}_{3}$ substituted complex $\mathbf{3} \mathbf{d L}_{2}$ was examined and the results are shown in Fig. S19.†

For $\mathbf{3} \mathbf{d L}_{2}$ the emission intensity decreases at high $\mathrm{pH}$ whilst the opposite is true for the unsubstituted complex $\mathbf{3} \mathbf{c L}_{2}$. Hence, as found for the phenylpyrazole complexes addition of a $\mathrm{CF}_{3}$ substituent to the $\mathrm{C}^{\wedge} \mathrm{N}$ ligand has the effect of reversing the slope of the pH curve. From the intensity changes a $\mathrm{p} K_{\mathrm{a}}$ value of 7.8 was determined (Fig. S19†), which is surprisingly similar to that of the unsubstituted complex ( $\mathrm{p} K_{\mathrm{a}} 8.0$ for $3 \mathbf{C L}_{2}$ ).

\section{Conclusions}

In conclusion, for all the complexes studied changes in $\mathrm{pH}$ gave only very minor changes in the associated UV-vis spectra over the full pH range studied. Hence, determining the ground state $\mathrm{p} K_{\mathrm{a}}$ was not feasible. In contrast, the emission intensity of the complexes was significantly modulated (by a factor of 1.2 to 2.9 ) by altering the $\mathrm{pH}$. Surprisingly the phenylpyrazole complexes $\mathbf{3 a L}_{1-3}$ showed an intensity decrease with increasing $\mathrm{pH}$ (switch off) whilst the phenylpyridine complexes $\mathbf{3} \mathbf{C L}_{1-3}$ showed an increase in emission intensity with increasing $\mathrm{pH}$. Changing the $\mathrm{R}$ group on the $\mathrm{N}^{\wedge} \mathrm{N}$ ligand had an effect of up to $1 \mathrm{pH}$ unit on the subsequent $\mathrm{p} K_{\mathrm{a}}$ values. However, the trends were not the same for the different series of complexes. More surprisingly, putting $\mathrm{CF}_{3}$ groups on the cyclometallated phenyls, i.e., complexes $\mathbf{3} \mathbf{b L}_{\mathbf{1 - 3}}$ and $\mathbf{3} \mathbf{d L}_{2}$, resulted in a complete reversal in the direction of the intensity change when compared to their respective unsubstituted congeners. The unsubstituted complexes had $\mathrm{p} K_{\mathrm{a}}$ values ranging from 8.0 to 10.0 and as anticipated, adding the electron-withdrawing group reduced the $\mathrm{p} K_{\mathrm{a}}$ of the complexes to 6.8-7.8, thereby extending to useful $\mathrm{p} K_{\mathrm{a}}$ range.

However, whilst adding $\mathrm{CF}_{3}$ substituents had the desired effect on the $\mathrm{p} K_{\mathrm{a}}$, in general it tended to reduce the proportional change in emission intensity per unit change in $\mathrm{pH}$. The reason(s) for this difference are not currently known. It is hoped that these studies will provide useful information for the design of other $\mathrm{pH}$ sensitive cyclometallated iridium complexes. 


\section{Experimental}

All reactions were carried out under an inert atmosphere of nitrogen unless otherwise mentioned though all work-up was carried out in air. Microwave reactions were carried out in a CEM Explorer hybrid 12 microwave synthesiser, solutions were degassed by bubbling nitrogen through the solution for 3 minutes before sealing the tube with a plastic cap. NMR spectra were recorded on a Bruker DRX400 spectrometer operating at $400.13\left({ }^{1} \mathrm{H}\right), 376.50\left({ }^{19} \mathrm{~F}\right), 100.61 \mathrm{MHz}\left({ }^{13} \mathrm{C}\right)$ and or a Bruker DRX500 spectrometer at $500\left({ }^{1} \mathrm{H}\right)$ and $125 \mathrm{MHz}\left({ }^{13} \mathrm{C}\right)$ respectively at ambient temperature; chemical shifts (ppm) are referred to the residual protic solvent peaks and coupling constants are expressed in Hertz (Hz). Assignments of ${ }^{1} \mathrm{H}$ and ${ }^{13} \mathrm{C}$ NMR signals were made where possible, using COSY, NOESY, TOCSY, HMQC, HMBC, DEPT and APT spectra. Electrospray (ES) and ASAP mass spectra were obtained using a micromass Qtra LC spectrometer in HPLC grade MeCN. The UV/Vis spectra measurements were carried out on a Shimadzu UV-1600 series spectrometer in $1 \mathrm{~cm}$ quartz cuvette at room temperature. Luminescence studies were performed on a Jobin Yvon Horiba Fluoromax-P spectrofluorimeter, in either reagent grade DCM or $\mathrm{MeOH}$, HPLC grade MeCN or spectroscopy grade DMF ( $N, N$-Dimethylformamide). Complexes were excited at a wavelength between $320-405 \mathrm{~nm}$ using a filter of 370,399 or $450 \mathrm{~nm}$. The $\mathrm{pH}$ values were determined using a Jenway $3510 \mathrm{pH}$ meter, calibrated prior to use with standard buffer solutions of $\mathrm{pH} \mathrm{4,6}$ and 10 at room temperature. The $\mathrm{p} K_{\mathrm{a}}$ values for all complexes were determined by the change of emission intensity upon the $\mathrm{pH}$ changing from about $c a .2 .5$ to 12.5 .

2-(1H-pyrazol-3-yl)pyridine ligands $\mathbf{H L}_{\mathbf{1 - 3}}$ were prepared by literature methods ${ }^{24}$ as were 1-(4-(trifluoromethyl)phenyl)- $1 H^{-}$ pyrazole $^{25}$ and 2-(4-(trifluoromethyl)phenyl)pyridine ${ }^{26}$ and the bis-cyclometallated dimers $\mathbf{1 a}-\mathbf{d}^{18}$ and the data are consistent with those published. ${ }^{18,19}$

\section{General procedure for the synthesis of cationic complexes [Ir $\left.\left(\mathbf{C}^{\wedge} \mathbf{N}\right)_{2}\left(\mathbf{H N}^{\wedge} \mathbf{N}\right)\right] \mathbf{P F}_{6}$}

The relevant dimer $\mathbf{1 a}, \mathbf{c}$, ligand $\left(\mathbf{H L}_{\mathbf{1}} / \mathbf{H L}_{2} / \mathbf{H L}_{3}\right)$ (2.2-2.4 equiv.) and $\mathrm{KPF}_{6}$ (2.4 equiv.) were placed in a microwave vial and methanol (3 ml) was added. After degassing with nitrogen the tube was heated under microwave irradiation at $60{ }^{\circ} \mathrm{C}$ for 20-40 min. After this time, the solvent was removed in vacuo leaving behind a solid which was dissolved in DCM $(15 \mathrm{ml})$ and passed through Celite. The filtrate was reduced in volume and hexane was added slowly to induce precipitation. The precipitate was isolated, washed with hexane and dried in vacuo. Samples could be recrystallised from DCM/hexane.

\section{General procedure for the synthesis of neutral complexes $\left[\operatorname{Ir}\left(\mathbf{C}^{\wedge} \mathbf{N}\right)_{2}\left(\mathbf{N}^{\wedge} \mathbf{N}\right)\right]$}

A mixture of the ligand $\left(\mathbf{H L}_{\mathbf{1}} / \mathbf{H L}_{\mathbf{2}} / \mathbf{H L}_{3}\right)(2.2-2.4$ equiv.) and an equimolar amount of $\mathrm{NaOMe}$ in $\mathrm{MeOH}(3 \mathrm{ml})$ was warmed gently at $40^{\circ} \mathrm{C}$ for $15 \mathrm{~min}$. A solution of the appropriate dimer 1a-d (1 equiv.) in DCM (6 $\mathrm{ml})$ was added and the mixture was stirred for $2-4 \mathrm{~h}$ at room temperature. After this time, the solvent was removed in vacuo and the residue was dissolved in DCM $(15 \mathrm{ml})$ and passed through Celite. The filtrate was reduced in volume and hexane was added slowly to induce precipitation. The precipitate was isolated, washed with hexane and dried in vacuo. Samples could be recrystallised from DCM/ hexane.

For all complexes the crude yields after washing but before recrystallisation are reported.

Synthesis of $2 \mathbf{a H L}_{\mathbf{1}}$. Using the general procedure, $2 \mathbf{a H L}_{\mathbf{1}}$ was prepared from 1a $(50 \mathrm{mg}, 0.049 \mathrm{mmol}), \mathbf{H L}_{\mathbf{1}}(16 \mathrm{mg}$, $0.10 \mathrm{mmol})$ and $\mathrm{KPF}_{6}(22 \mathrm{mg}, 0.12 \mathrm{mmol})$. After work up, the compound was isolated as a grey yellow solid $(58 \mathrm{mg}, 78 \%),{ }^{1} \mathrm{H}$ NMR ( $\left.500 \mathrm{MHz}, \mathrm{CD}_{3} \mathrm{CN}, 300 \mathrm{~K}\right): \delta 8.40\left(1 \mathrm{H}, \mathrm{d}, J=2.9 \mathrm{~Hz}, \mathrm{H}_{5 \mathrm{~B}}\right)$, $8.36\left(1 \mathrm{H}, \mathrm{d}, J=2.9 \mathrm{~Hz}, \mathrm{H}_{5 \mathrm{~A}}\right), 8.20\left(1 \mathrm{H}, \mathrm{dt}, J=7.9,0.9 \mathrm{~Hz}, \mathrm{H}_{\mathrm{e}}\right)$, $8.10\left(1 \mathrm{H}, \mathrm{td}, J=7.9,1.7 \mathrm{~Hz}, \mathrm{H}_{\mathrm{f}}\right), 8.01(1 \mathrm{H}, \mathrm{ddd}, J=5.5,1.7,0.8$ $\left.\mathrm{Hz}, \mathrm{H}_{\mathrm{h}}\right), 7.83\left(1 \mathrm{H}, \mathrm{d}, J=2.9 \mathrm{~Hz}, \mathrm{H}_{\mathrm{a}}\right), 7.50(1 \mathrm{H}, \mathrm{dd}, J=4.7,1.0$ $\left.\mathrm{Hz}, \mathrm{H}_{4 \mathrm{~B}}\right), 7.47\left(1 \mathrm{H}, \mathrm{dd}, J=4.7,1.0 \mathrm{~Hz}, \mathrm{H}_{4 \mathrm{~A}}\right), 7.37(1 \mathrm{H}, \mathrm{ddd}, J=$ $\left.7.7,5.5,1.3 \mathrm{~Hz}, \mathrm{H}_{\mathrm{g}}\right), 7.20\left(1 \mathrm{H}, \mathrm{d}, J=2.9 \mathrm{~Hz}, \mathrm{H}_{\mathrm{b}}\right), 7.11-7.03(3 \mathrm{H}$, $\left.\mathrm{m}, \mathrm{H}_{3 \mathrm{~A}, 3 \mathrm{~B}, 7 \mathrm{~B}}\right), 7.01\left(1 \mathrm{H}, \mathrm{d}, J=2.2 \mathrm{~Hz}, \mathrm{H}_{7 \mathrm{~A}}\right), 6.90(1 \mathrm{H}, \mathrm{td}, J=7.5$, $\left.1.2 \mathrm{~Hz}, \mathrm{H}_{2 \mathrm{~B}}\right), 6.85\left(1 \mathrm{H}, \mathrm{td}, J=7.5,1.2 \mathrm{~Hz}, \mathrm{H}_{2 \mathrm{~A}}\right), 6.62(1 \mathrm{H}, \mathrm{t}$ overlapping, $\left.J=2.7 \mathrm{~Hz}, \mathrm{H}_{6 \mathrm{~B}}\right), 6.61(1 \mathrm{H}, \mathrm{t}$ overlapping, $J=2.7 \mathrm{~Hz}$, $\left.\mathrm{H}_{6 \mathrm{~A}}\right), 6.32\left(1 \mathrm{H}, \mathrm{dd}, J=5.0,1.3 \mathrm{~Hz}, \mathrm{H}_{1 \mathrm{~B}}\right), 6.30(1 \mathrm{H}, \mathrm{dd}, J=5.1$, $\left.1.3 \mathrm{~Hz}, \mathrm{H}_{1 \mathrm{~A}}\right) \cdot{ }^{13} \mathrm{C}$ NMR $\left(125 \mathrm{MHz}, \mathrm{CD}_{3} \mathrm{CN}, 300 \mathrm{~K}\right): \delta 154.0\left(\mathrm{C}_{\mathrm{c}}\right)$, $153.3\left(\mathrm{C}_{\mathrm{d}}\right), 151.8\left(\mathrm{C}_{\mathrm{h}}\right), 144.8\left(\mathrm{C}_{9 \mathrm{~A} / 9 \mathrm{~B}}\right), 144.6\left(\mathrm{C}_{9 \mathrm{~A} / 9 \mathrm{~B}}\right), 140.6\left(\mathrm{C}_{\mathrm{f}}\right)$, $140.1\left(\mathrm{C}_{7 \mathrm{~A}}\right), 139.7\left(\mathrm{C}_{7 \mathrm{~B}}\right), 135.0\left(\mathrm{C}_{\mathrm{a}}\right), 134.4\left(\mathrm{C}_{1 \mathrm{~A} / 1 \mathrm{~B}}\right), 134.1$ $\left(\mathrm{C}_{1 \mathrm{~A} / 1 \mathrm{~B}}\right), 132.4\left(\mathrm{C}_{8 \mathrm{~A} / 8 \mathrm{~B}}\right), 128.8\left(\mathrm{C}_{5 \mathrm{~B}}\right), 128.7\left(\mathrm{C}_{5 \mathrm{~A}}\right), 128.6\left(\mathrm{C}_{8 \mathrm{~A} / 8 \mathrm{~B}}\right)$, $127.5\left(\mathrm{C}_{2 \mathrm{~A} / 2 \mathrm{~B}}\right), 127.1\left(\mathrm{C}_{2 \mathrm{~A} / 2 \mathrm{~B}}\right), 127.0\left(\mathrm{C}_{\mathrm{g}}\right), 124.3\left(\mathrm{C}_{3 \mathrm{~A} / 3 \mathrm{~B}}\right), 124.2$ $\left(\mathrm{C}_{3 \mathrm{~A} / 3 \mathrm{~B}}\right), 123.9\left(\mathrm{C}_{\mathrm{e}}\right), 113.0\left(\mathrm{C}_{4 \mathrm{~B}}\right), 112.7\left(\mathrm{C}_{4 \mathrm{~A}}\right), 109.3\left(\mathrm{C}_{6 \mathrm{~A} / 6 \mathrm{~B}}\right)$, $109.1\left(\mathrm{C}_{6 \mathrm{~A} / 6 \mathrm{~B}}\right), 106.3\left(\mathrm{C}_{\mathrm{b}}\right)$. HRMS (ASAP): $\mathrm{m} / \mathrm{z} 624.1497$ [624.1488 calculated for $\left.\mathrm{C}_{26} \mathrm{H}_{21}{ }^{193} \mathrm{IrN}_{7}\right]$.

Synthesis of $2 \mathbf{a H L}_{2}$. This was prepared from dimer $\mathbf{1 a}$ (71 $\mathrm{mg}, 0.07 \mathrm{mmol}) \mathbf{H L}_{2}\left(31 \mathrm{mg}, 0.154 \mathrm{mmol}\right.$ ) and $\mathrm{KPF}_{6}$ (31 mg, $0.168 \mathrm{mmol}$ ). After work up, the compound was isolated as a yellow solid (107 mg, 93\%). ${ }^{1} \mathrm{H}$ NMR $(500 \mathrm{MHz}$, $\left.\mathrm{CD}_{2} \mathrm{Cl}_{2}, 300 \mathrm{~K}\right): \delta 8.20\left(1 \mathrm{H}, \mathrm{d}, J=2.5 \mathrm{~Hz}, \mathrm{H}_{5 \mathrm{~B}}\right), 8.13(1 \mathrm{H}, \mathrm{d}, J=$ $\left.2.5 \mathrm{~Hz}, \mathrm{H}_{5 \mathrm{~A}}\right), 8.07-7.98\left(3 \mathrm{H}, \mathrm{m}, \mathrm{H}_{\mathrm{e}, \mathrm{f}, \mathrm{h}}\right), 7.38(1 \mathrm{H}, \mathrm{dd}, J=8.0,0.9$ $\left.\mathrm{Hz}, \mathrm{H}_{4 \mathrm{~B}}\right), 7.33-7.28\left(2 \mathrm{H}, \mathrm{m}, \mathrm{H}_{4 \mathrm{~A}} \mathrm{H}_{\mathrm{g}}\right), 7.08(2 \mathrm{H}, 2 \times \mathrm{td}, J=7.6$, $\left.1.3 \mathrm{~Hz}, \mathrm{H}_{3 \mathrm{~A}, 3 \mathrm{~B}}\right), 6.93\left(1 \mathrm{H}\right.$, br. $\left.\mathrm{d}, J=1.8 \mathrm{~Hz}, \mathrm{H}_{7 \mathrm{~B}}\right), 6.91-6.84(4 \mathrm{H}$, $\left.\mathrm{m}, \mathrm{H}_{2 \mathrm{~B}}, \mathrm{H}_{2 \mathrm{~A}}, \mathrm{H}_{\mathrm{b}}, \mathrm{H}_{7 \mathrm{~A}}\right), 6.60\left(1 \mathrm{H}, \mathrm{t}, J=2.6 \mathrm{~Hz}, \mathrm{H}_{6 \mathrm{~B}}\right), 6.58(1 \mathrm{H}, \mathrm{t}$, $\left.J=2.6 \mathrm{~Hz}, \mathrm{H}_{6 \mathrm{~A}}\right), 6.37\left(1 \mathrm{H}, \mathrm{dd}, J=7.6,1.2 \mathrm{~Hz}, \mathrm{H}_{1 \mathrm{~B}}\right), 6.27(1 \mathrm{H}$, $\left.\mathrm{dd}, J=7.6,1.2 \mathrm{~Hz}, \mathrm{H}_{1 \mathrm{~A}}\right), 1.35\left(9 \mathrm{H}, \mathrm{s}, \mathrm{H}_{\mathrm{Bu}}^{t}\right) \cdot{ }^{13} \mathrm{C}$ NMR $(125 \mathrm{MHz}$, $\left.\mathrm{CD}_{2} \mathrm{Cl}_{2}, 300 \mathrm{~K}\right): \delta 159.2\left(\mathrm{C}_{\mathrm{a}}\right), 153.4\left(\mathrm{C}_{\mathrm{q}}\right), 152.9\left(\mathrm{C}_{\mathrm{q}}\right), 151.0\left(\mathrm{C}_{\mathrm{h}}\right)$, $144.0\left(\mathrm{C}_{\mathrm{q}}\right), 143.8\left(\mathrm{C}_{\mathrm{q}}\right), 139.9\left(\mathrm{C}_{\mathrm{f}}\right), 139.1\left(\mathrm{C}_{7 \mathrm{~A}}\right), 138.7\left(\mathrm{C}_{7 \mathrm{~B}}\right), 127.2$ $\left(\mathrm{C}_{5 \mathrm{~B}}\right), 126.7\left(\mathrm{C}_{5 \mathrm{~A}}\right), 134.3\left(\mathrm{C}_{1 \mathrm{~B}}\right), 133.5\left(\mathrm{C}_{1 \mathrm{~A}}\right), 130.8\left(\mathrm{C}_{9 \mathrm{~A} / 9 \mathrm{~B}}\right), 128.6$ $\left(\mathrm{C}_{9 \mathrm{~A} / 9 \mathrm{~B}}\right), 127.5\left(\mathrm{C}_{2 \mathrm{~A} / 2 \mathrm{~B}}\right), 127.4\left(\mathrm{C}_{2 \mathrm{~A} / 2 \mathrm{~B}}\right), 126.2\left(\mathrm{C}_{\mathrm{g}}\right), 123.9\left(\mathrm{C}_{3 \mathrm{~A} / 3 \mathrm{~B}}\right)$, $123.8\left(\mathrm{C}_{3 \mathrm{~A} / 3 \mathrm{~B}}\right), 123.0\left(\mathrm{C}_{\mathrm{e}}\right), 112.2\left(\mathrm{C}_{4 \mathrm{~A}}\right), 112.1\left(\mathrm{C}_{4 \mathrm{~B}}\right), 108.7\left(\mathrm{C}_{6 \mathrm{~A}}\right)$, $108.5\left(\mathrm{C}_{6 \mathrm{~B}}\right), 102.2\left(\mathrm{C}_{\mathrm{b}}\right), 32.1\left(\mathrm{C}_{\mathrm{i}}\right), 30.0\left(\mathrm{Ct}_{\mathrm{Bu}}\right)$. HRMS (ASAP): $\mathrm{m} / \mathrm{z}$ 680.2145 [680.2114 calculated for $\left.\mathrm{C}_{30} \mathrm{H}_{29}{ }^{193} \operatorname{IrN}_{7}\right]$.

Synthesis of $2 \mathrm{aHL}_{3}$. This was prepared from dimer $\mathbf{1 a}$ (50 mg, $0.046 \mathrm{mmol}) \mathbf{H L}_{3}(23 \mathrm{mg}, 0.11 \mathrm{mmol})$ and $\mathrm{KPF}_{6}$ (21 mg, $0.12 \mathrm{mmol}$ ). After work up, the crude material was purified by column chromatography on silica gel DCM/ethyl acetate $(2: 1)$ to give a grey yellowish solid $(68 \mathrm{mg}, 82 \%) .{ }^{1} \mathrm{H}$ NMR ( $\left.500 \mathrm{MHz}, \mathrm{CD}_{3} \mathrm{CN}, 298 \mathrm{~K}\right): \delta 8.41\left(1 \mathrm{H}, \mathrm{d}, J=2.7 \mathrm{~Hz}, \mathrm{H}_{5 \mathrm{~B}}\right)$, $8.36\left(1 \mathrm{H}, \mathrm{d}, J=2.7 \mathrm{~Hz}, \mathrm{H}_{5 \mathrm{~A}}\right), 8.22\left(1 \mathrm{H}\right.$, br. d, $\left.J=7.8 \mathrm{~Hz}, \mathrm{H}_{\mathrm{e}}\right)$, 
$8.10\left(1 \mathrm{H}, \mathrm{td}, J=7.8,1.1 \mathrm{~Hz}, \mathrm{H}_{\mathrm{f}}\right), 7.99\left(1 \mathrm{H}\right.$, br. d, $\left.J=5.3 \mathrm{~Hz}, \mathrm{H}_{\mathrm{h}}\right)$, $7.74\left(2 \mathrm{H}\right.$, br. $\left.\mathrm{d}, J=6.9 \mathrm{~Hz}, \mathrm{H}_{\mathrm{j}, \mathrm{k}}\right), 7.55-7.46(6 \mathrm{H}, \mathrm{m}$, $\left.\mathrm{H}_{\mathrm{b}, l, \mathrm{~m}, \mathrm{n}, 4 \mathrm{~A}, 4 \mathrm{~B}}\right), 7.38\left(1 \mathrm{H}\right.$, br. $\left.\mathrm{t}, J=6.2 \mathrm{~Hz}, \mathrm{H}_{\mathrm{g}}\right), 7.21(1 \mathrm{H}, \mathrm{d}, J=2.1$ $\left.\mathrm{Hz}, \mathrm{H}_{7 \mathrm{~A}}\right), 7.10-7.04\left(3 \mathrm{H}, \mathrm{m}, \mathrm{H}_{3 \mathrm{~A}, 3 \mathrm{~B}, 7 \mathrm{~B}}\right), 6.89(1 \mathrm{H}, \mathrm{t} J=7.3 \mathrm{~Hz}$, $\left.\mathrm{H}_{2 \mathrm{~A} / 2 \mathrm{~B}}\right), 6.86\left(1 \mathrm{H}, \mathrm{t} J=7.3 \mathrm{~Hz}, \mathrm{H}_{2 \mathrm{~A} / 2 \mathrm{~B}}\right), 6.63(1 \mathrm{H}, \mathrm{t}, J=2.5 \mathrm{~Hz}$, $\left.\mathrm{H}_{6 \mathrm{~A}}\right), 6.61\left(1 \mathrm{H}, \mathrm{t}, J=2.5 \mathrm{~Hz}, \mathrm{H}_{6 \mathrm{~B}}\right), 6.32\left(1 \mathrm{H}, \mathrm{d}, J=7.3 \mathrm{~Hz}, \mathrm{H}_{1 \mathrm{~B}}\right)$, $6.28\left(1 \mathrm{H}, \mathrm{d}, J=7.3 \mathrm{~Hz}, \mathrm{H}_{1 \mathrm{~A}}\right) \cdot{ }^{13} \mathrm{C}$ NMR: $\left(125 \mathrm{MHz}, \mathrm{CD}_{3} \mathrm{CN}\right.$, $298 \mathrm{~K}): \delta 155.0\left(\mathrm{C}_{\mathrm{q}}\right), 153.2\left(\mathrm{C}_{\mathrm{q}}\right), 151.6\left(\mathrm{C}_{\mathrm{h}}\right), 149.0\left(\mathrm{C}_{\mathrm{q}}\right), 145.0$ $\left(\mathrm{C}_{\mathrm{q}}\right), 144.6\left(\mathrm{C}_{\mathrm{q}}\right), 140.7\left(\mathrm{C}_{\mathrm{f}}\right), 140.3\left(\mathrm{C}_{7 \mathrm{~A}}\right), 139.7\left(\mathrm{C}_{7 \mathrm{~B}}\right), 135.3$ $\left(\mathrm{C}_{1 \mathrm{~A} / 1 \mathrm{~B}}\right), 134.0\left(\mathrm{C}_{1 \mathrm{~A} / 1 \mathrm{~B}}\right), 132.2\left(\mathrm{C}_{\mathrm{q}}\right), 130.8\left(\mathrm{C}_{\mathrm{n}}\right), 130.2\left(2 \mathrm{C}_{\mathrm{l}, \mathrm{m}}\right)$, $129.0\left(\mathrm{C}_{\mathrm{q}}\right), 128.8\left(\mathrm{C}_{5 \mathrm{~A}}\right), 128.7\left(\mathrm{C}_{5 \mathrm{~B}}\right), 128.4\left(\mathrm{C}_{\mathrm{q}}\right), 127.7\left(2 \mathrm{C}_{\mathrm{j}, \mathrm{k}}\right)$, $127.5\left(\mathrm{C}_{2 \mathrm{~A} / 2 \mathrm{~B}}\right), 127.2\left(\mathrm{C}_{2 \mathrm{~A} / 2 \mathrm{~B}}\right), 127.0\left(\mathrm{C}_{\mathrm{g}}\right), 124.4\left(\mathrm{C}_{3 \mathrm{~A} / 3 \mathrm{~B}}\right), 124.1$ $\left(\mathrm{C}_{3 \mathrm{~A} / 3 \mathrm{~B}}\right), 124.0\left(\mathrm{C}_{\mathrm{e}}\right), 113.0\left(\mathrm{C}_{4 \mathrm{~A} / 4 \mathrm{~B}}\right), 112.6\left(\mathrm{C}_{4 \mathrm{~A} / 4 \mathrm{~B}}\right), 109.3\left(\mathrm{C}_{6 \mathrm{~B}}\right)$, $109.1\left(\mathrm{C}_{6 \mathrm{~A}}\right), 104.0\left(\mathrm{C}_{\mathrm{b}}\right)$. HRMS (ASAP): $\mathrm{m} / \mathrm{z} 700.1821$ [700.1801 calculated for $\left.\mathrm{C}_{32} \mathrm{H}_{25}{ }^{193} \mathrm{IrN}_{7}\right]$.

Synthesis of $\mathbf{3 a L}_{\mathbf{1}}$. This was prepared from dimer $\mathbf{1 a}(50 \mathrm{mg}$, $0.08 \mathrm{mmol}$ ), $\mathbf{H L}_{\mathbf{1}}(16 \mathrm{mg}, 0.11 \mathrm{mmol}$ ) and NaOMe $(5 \mathrm{mg}$, $0.11 \mathrm{mmol}$ ). After work up, the crude product was purified by column chromatography (aluminium oxide); the product was eluted with $\mathrm{CH}_{2} \mathrm{Cl}_{2} / \mathrm{MeOH}$ (30:1), respectively. 3aL 1 was isolated as a grey yellow solid (45 mg, 76\%). ${ }^{1} \mathrm{H}$ NMR: $(500 \mathrm{MHz}$, $\left.\mathrm{CD}_{3} \mathrm{CN}, 298 \mathrm{~K}\right): \delta 8.29\left(1 \mathrm{H}, \mathrm{d}, J=2.7 \mathrm{~Hz}, \mathrm{H}_{5 \mathrm{~B}}\right), 8.26(1 \mathrm{H}, \mathrm{d}, J=$ $\left.2.7 \mathrm{~Hz}, \mathrm{H}_{5 \mathrm{~A}}\right), 7.90-7.86\left(2 \mathrm{H}, \mathrm{m} \mathrm{Hz}, \mathrm{H}_{\mathrm{h}, \mathrm{e}}\right), 7.83(1 \mathrm{H}, \mathrm{td}, J=7.7$, $\left.1.5 \mathrm{~Hz}, \mathrm{H}_{\mathrm{f}}\right), 7.47\left(1 \mathrm{H}, \mathrm{d}, J=2.1 \mathrm{~Hz}, \mathrm{H}_{\mathrm{a}}\right), 7.39(1 \mathrm{H}, \mathrm{d}, J=7.6 \mathrm{~Hz}$, $\left.\mathrm{H}_{4 \mathrm{~A}}\right), 7.35\left(1 \mathrm{H}, \mathrm{d}, J=7.8 \mathrm{~Hz}, \mathrm{H}_{4 \mathrm{~B}}\right), 7.06(1 \mathrm{H}, \mathrm{ddd}, J=7.6,5.6$, $\left.1.2 \mathrm{~Hz}, \mathrm{H}_{\mathrm{g}}\right), 7.00-6.95\left(2 \mathrm{H}, \mathrm{m}, \mathrm{H}_{7 \mathrm{~B}}, \mathrm{H}_{3 \mathrm{~A}}\right), 6.91(1 \mathrm{H}, \mathrm{td}, J=7.7$, $\left.1.1 \mathrm{~Hz}, \mathrm{H}_{3 \mathrm{~B}}\right), 6.82-6.80\left(2 \mathrm{H}, \mathrm{m}, \mathrm{H}_{\mathrm{b}}, \mathrm{H}_{2 \mathrm{~A}}\right), 6.72-6.69(2 \mathrm{H}, \mathrm{m}$, $\left.\mathrm{H}_{2 \mathrm{~B}, 7 \mathrm{~A}}\right), 6.53\left(1 \mathrm{H}, \mathrm{t}, J=2.5 \mathrm{~Hz}, \mathrm{H}_{6 \mathrm{~B}}\right), 6.50(1 \mathrm{H}, \mathrm{t}, J=2.5 \mathrm{~Hz}$, $\left.\mathrm{H}_{6 \mathrm{~A}}\right), 6.34\left(1 \mathrm{H}, \mathrm{dd}, J=7.3,1.0 \mathrm{~Hz}, \mathrm{H}_{1 \mathrm{~A}}\right), 6.22(1 \mathrm{H}, \mathrm{dd}, J=7.4$, $\left.1.0 \mathrm{~Hz}, \mathrm{H}_{1 \mathrm{~B}}\right) .{ }^{13} \mathrm{C}$ NMR (125 MHz, MeOD, $\left.298 \mathrm{~K}\right): \delta 154.4\left(\mathrm{C}_{\mathrm{c}}\right)$, $154.1\left(\mathrm{C}_{\mathrm{d}}\right), 151.7\left(\mathrm{C}_{\mathrm{h}}\right), 145.2\left(\mathrm{C}_{8 \mathrm{~A} / 8 \mathrm{~B}}\right), 145.1\left(\mathrm{C}_{8 \mathrm{~A} / 8 \mathrm{~B}}\right), 140.9\left(\mathrm{C}_{\mathrm{f}}\right)$, $140.0\left(\mathrm{C}_{7 \mathrm{~A} / 7 \mathrm{~B}}\right), 139.5\left(\mathrm{C}_{7 \mathrm{~A} / 7 \mathrm{~B}}\right), 135.2\left(\mathrm{C}_{1 \mathrm{~B}}\right), 134.9\left(\mathrm{C}_{\mathrm{a}}\right), 134.4$ $\left(\mathrm{C}_{1 \mathrm{~A}}\right), 132.7\left(\mathrm{C}_{9 \mathrm{~A} / 9 \mathrm{~B}}\right), 129.2\left(\mathrm{C}_{9 \mathrm{~A} / 9 \mathrm{~B}}\right), 128.9\left(\mathrm{C}_{5 \mathrm{~A}}\right), 128.8\left(\mathrm{C}_{5 \mathrm{~B}}\right)$, $127.7\left(\mathrm{C}_{2 \mathrm{~A} / 2 \mathrm{~B}}\right), 127.3\left(\mathrm{C}_{2 \mathrm{~A} / 2 \mathrm{~B}}\right), 127.1\left(\mathrm{C}_{\mathrm{g}}\right), 124.5\left(\mathrm{C}_{3 \mathrm{~A} / 3 \mathrm{~B}}\right), 124.3$ $\left(\mathrm{C}_{3 \mathrm{~A} / 3 \mathrm{~B}}\right), 124.0\left(\mathrm{C}_{\mathrm{e}}\right), 113.0\left(\mathrm{C}_{4 \mathrm{~A} / 4 \mathrm{~B}}\right), 112.8\left(\mathrm{C}_{4 \mathrm{~A} / 4 \mathrm{~B}}\right), 109.5\left(\mathrm{C}_{6 \mathrm{~A} / 6 \mathrm{~B}}\right)$, $109.3\left(\mathrm{C}_{6 \mathrm{~A} / 6 \mathrm{~B}}\right), 106.4\left(\mathrm{C}_{\mathrm{b}}\right)$. HRMS (ASAP): $[\mathrm{M}+\mathrm{H}]^{+}, \mathrm{m} / z 624.1489$ [624.1488 calculated for $\mathrm{C}_{26} \mathrm{H}_{21}{ }^{193} \mathrm{IrN}_{7}$ ].

Synthesis of $3 \mathrm{aL}_{2}$. This was prepared from dimer $\mathbf{1 a}(71 \mathrm{mg}$, $0.069 \mathrm{mmol}$ ), $\mathbf{H L}_{2}$ (31 $\mathrm{mg}, 0.15 \mathrm{mmol}$ ) and NaOMe (30 mg, $0.15 \mathrm{mmol})$ in $\mathrm{MeOH}(3 \mathrm{ml})$ and DCM $(6 \mathrm{ml})$, and was allowed to stir for $2.5 \mathrm{~h}$. After work up, $\mathbf{3} \mathbf{a L}_{2}$ was isolated as grey yellow solid (73 mg, 76\%). ${ }^{1} \mathrm{H}$ NMR (500 MHz, $\left.\mathrm{CDCl}_{3}, 300 \mathrm{~K}\right): \delta 7.93(1 \mathrm{H}, \mathrm{d}, J$ $\left.=2.9 \mathrm{~Hz}, \mathrm{H}_{5 \mathrm{~A} / \mathrm{B}}\right), 7.84\left(2 \mathrm{H}\right.$, br. $\left.\mathrm{m}, \mathrm{H}_{5 \mathrm{~A} / \mathrm{B}, \mathrm{h}}\right), 7.63$ (1H, br. d, $J=7.4$ $\left.\mathrm{Hz}, \mathrm{H}_{\mathrm{e}}\right), 7.60\left(1 \mathrm{H}, \mathrm{td}, J=7.7,1.3 \mathrm{~Hz}, \mathrm{H}_{\mathrm{f}}\right), 7.15(1 \mathrm{H}, \mathrm{d}, J=7.7 \mathrm{~Hz}$, $\left.\mathrm{H}_{4 \mathrm{~A} / \mathrm{B}}\right), 7.11\left(1 \mathrm{H}, \mathrm{d}, J=7.6 \mathrm{~Hz}, \mathrm{H}_{4 \mathrm{~A} / \mathrm{B}}\right), 6.91(1 \mathrm{H}, \mathrm{td}, J=7.6,1.1 \mathrm{~Hz}$, $\left.\mathrm{H}_{3 \mathrm{~B}}\right), 6.86\left(1 \mathrm{H}, \mathrm{td}, J=7.6,0.8 \mathrm{~Hz}, \mathrm{H}_{3 \mathrm{~A}}\right), 6.82-6.72(5 \mathrm{H}, \mathrm{m}$,

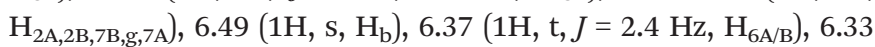
$\left(1 \mathrm{H}, \mathrm{dd}, J=7.6,1.1 \mathrm{~Hz}, \mathrm{H}_{1 \mathrm{~A}}\right), 6.30\left(1 \mathrm{H}, \mathrm{dd}, J=7.5,1.1 \mathrm{~Hz}, \mathrm{H}_{1 \mathrm{~B}}\right)$, $6.20\left(1 \mathrm{H}, \mathrm{t}, J=2.4 \mathrm{~Hz}, \mathrm{H}_{6 \mathrm{~A} / \mathrm{B}}\right), 1.29\left(9 \mathrm{H}, \mathrm{s}, \mathrm{H}_{\mathrm{Bu}}^{t}\right){ }^{13} \mathrm{C}$ NMR: (125 MHz, $\left.\mathrm{CDCl}_{3}, 300 \mathrm{~K}\right): \delta 163.9\left(\mathrm{C}_{\mathrm{q}}\right), 157.2\left(\mathrm{C}_{\mathrm{q}}\right), 149.5\left(\mathrm{C}_{\mathrm{q}}\right)$, 149.4 (CH), $144.1\left(\mathrm{C}_{\mathrm{q}}\right), 143.3\left(\mathrm{C}_{\mathrm{q}}\right), 138.7(\mathrm{CH}), 137.3(\mathrm{CH}), 137.1$ $\left(\mathrm{C}_{\mathrm{q}}\right), 136.8(\mathrm{CH}), 134.0\left(\mathrm{C}_{1 \mathrm{~A} / 1 \mathrm{~B}}\right), 133.7\left(\mathrm{C}_{1 \mathrm{~A} / 1 \mathrm{~B}}\right), 133.0\left(\mathrm{C}_{\mathrm{q}}\right), 126.3$ $(\mathrm{CH}), 126.0(\mathrm{CH}), 125.6(\mathrm{CH}), 125.4(\mathrm{CH}), 122.0(\mathrm{CH}), 121.5(\mathrm{CH})$, $120.7(\mathrm{CH}), 119.0(\mathrm{CH}), 111.1(\mathrm{CH}), 110.8(\mathrm{CH}), 107.3(\mathrm{CH}), 107.0$ $(\mathrm{CH}), 98.8\left(\mathrm{C}_{\mathrm{b}}\right), 32.2\left(\mathrm{C}_{\mathrm{i}}\right), 31.2\left(\mathrm{C}_{\mathrm{Bu}}^{t}\right)$. HRMS (ASAP): $[\mathrm{M}+\mathrm{H}]^{+}, \mathrm{m} / z$ 680.2115 [680.2114 calculated for $\mathrm{C}_{30} \mathrm{H}_{29}{ }^{193} \mathrm{IrN}_{7}$ ].
Synthesis of $3 \mathbf{a L}_{3}$. This was prepared from dimer $\mathbf{1 a}(50 \mathrm{mg}$, $0.048 \mathrm{mmol}), \mathbf{H L}_{3}(23.7 \mathrm{mg}, 0.11 \mathrm{mmol})$ and NaOMe (6 mg, $0.11 \mathrm{mmol})$ in $\mathrm{MeOH}(3 \mathrm{ml})$ and DCM $(6 \mathrm{ml})$. After work up, the compound was isolated as a pale yellow solid (47 mg, $69 \%) .{ }^{1} \mathrm{H}$ NMR (500 MHz, $\left.\mathrm{CD}_{2} \mathrm{Cl}_{2}, 298 \mathrm{~K}\right): \delta 8.01(1 \mathrm{H}, \mathrm{dd}, J=$ $\left.3.0,0.4 \mathrm{~Hz}, \mathrm{H}_{5 \mathrm{~A}}\right), 7.94\left(1 \mathrm{H}, \mathrm{dd}, J=2.9,0.4 \mathrm{~Hz}, \mathrm{H}_{5 \mathrm{~B}}\right), 7.82(1 \mathrm{H}$, ddd, $\left.J=5.5,1.4,0.8 \mathrm{~Hz}, \mathrm{H}_{\mathrm{h}}\right), 7.70-7.67\left(3 \mathrm{H}, \mathrm{m}, \mathrm{H}_{\mathrm{e}, \mathrm{j}, \mathrm{k}}\right), 7.63$ $\left(1 \mathrm{H}, \mathrm{td}, J=7.7,1.2 \mathrm{~Hz}, \mathrm{H}_{\mathrm{f}}\right), 7.23-7.16\left(4 \mathrm{H}, \mathrm{m}, \mathrm{H}_{4 \mathrm{~A}, 4 \mathrm{~B}, l, \mathrm{~m}}\right)$, 7.09-7.05 (1H, m, Hz, $\left.\mathrm{H}_{\mathrm{n}}\right), 6.95\left(1 \mathrm{H}, \mathrm{s}, \mathrm{H}_{\mathrm{b}}\right), 6.92(1 \mathrm{H}, \mathrm{td}, J=$ 7.7, $\left.1.3 \mathrm{~Hz}, \mathrm{H}_{3 \mathrm{~A}}\right), 6.90\left(1 \mathrm{H}, \mathrm{td}, J=7.7,1.3 \mathrm{~Hz}, \mathrm{H}_{3 \mathrm{~B}}\right), 6.85(1 \mathrm{H}, \mathrm{d}$, $\left.J=1.6 \mathrm{~Hz}, \mathrm{H}_{7 \mathrm{~A}}\right), 6.84-6.80\left(2 \mathrm{H}, \mathrm{m}, \mathrm{H}_{7 \mathrm{~B}, \mathrm{~g}}\right), 6.76(1 \mathrm{H}, \mathrm{td}, J=7.4$, $\left.1.2 \mathrm{~Hz}, \mathrm{H}_{2 \mathrm{~A}}\right), 6.73\left(1 \mathrm{H}, \mathrm{td}, J=7.4,1.2 \mathrm{~Hz}, \mathrm{H}_{2 \mathrm{~B}}\right), 6.40(1 \mathrm{H}, \mathrm{t}, J=$ $\left.2.5 \mathrm{~Hz}, \mathrm{H}_{6 \mathrm{~B}}\right), 6.35\left(1 \mathrm{H}, \mathrm{t}, J=2.5 \mathrm{~Hz}, \mathrm{H}_{6 \mathrm{~A}}\right), 6.33(1 \mathrm{H}, \mathrm{dd}, J=7.4$, $\left.1.2 \mathrm{~Hz}, \mathrm{H}_{1 \mathrm{~A}}\right), 6.28\left(1 \mathrm{H}, \mathrm{dd}, J=7.5,1.1 \mathrm{~Hz}, \mathrm{H}_{1 \mathrm{~B}}\right) .{ }^{13} \mathrm{C} \mathrm{NMR}$ $\left(125 \mathrm{MHz}, \mathrm{CD}_{2} \mathrm{Cl}_{2}, 298 \mathrm{~K}\right): \delta 157.1\left(\mathrm{C}_{\mathrm{q}}\right), 153.6\left(\mathrm{C}_{\mathrm{q}}\right), 152.0\left(\mathrm{C}_{\mathrm{q}}\right)$, $150.1\left(\mathrm{C}_{\mathrm{h}}\right), 144.5\left(\mathrm{C}_{\mathrm{q}}\right), 143.6\left(\mathrm{C}_{\mathrm{q}}\right), 139.1\left(\mathrm{C}_{7 \mathrm{~B}}\right), 138.2\left(\mathrm{C}_{\mathrm{f}}\right), 137.6$ $\left(\mathrm{C}_{\mathrm{q}}\right), 137.5\left(\mathrm{C}_{7 \mathrm{~A}}\right), 136.1\left(\mathrm{C}_{\mathrm{q}}\right), 134.3\left(\mathrm{C}_{1 \mathrm{~A}}\right), 134.1\left(\mathrm{C}_{1 \mathrm{~B}}\right), 133.7\left(\mathrm{C}_{\mathrm{q}}\right)$, $128.7\left(2 \mathrm{C}_{\mathrm{l} / \mathrm{m}}\right), 126.6(\mathrm{CH}), 126.4(2 \mathrm{CH}), 126.2(\mathrm{CH}), 126.0(\mathrm{CH})$, $125.4\left(2 \mathrm{C}_{\mathrm{j}, \mathrm{k}}\right), 122.5\left(\mathrm{C}_{2 \mathrm{~A} / 2 \mathrm{~B}}\right), 121.8\left(\mathrm{C}_{2 \mathrm{~A} / 2 \mathrm{~B}}\right), 121.7\left(\mathrm{C}_{\mathrm{g}}\right), 119.7$ $(\mathrm{CH}), 111.4\left(\mathrm{C}_{4 \mathrm{~A} / 4 \mathrm{~B}}\right), 111.3\left(\mathrm{C}_{4 \mathrm{~A} / 4 \mathrm{~B}}\right), 107.8\left(\mathrm{C}_{6 \mathrm{~A}}\right), 107.5\left(\mathrm{C}_{6 \mathrm{~B}}\right)$, $100.7\left(\mathrm{C}_{\mathrm{b}}\right)$. HRMS (ASAP): $[\mathrm{M}+\mathrm{H}]^{+}, \mathrm{m} / z$ 700.1818 [700.1801 calculated for $\left.\mathrm{C}_{32} \mathrm{H}_{25}{ }^{193} \mathrm{IrN}_{7}\right]$.

Synthesis of $\mathbf{3} \mathbf{b L}_{\mathbf{1}}$. This was prepared from the dimer $\mathbf{1 b}$ (60 mg, $0.046 \mathrm{mmol}$ ), $\mathbf{H L}_{\mathbf{1}}(14.7 \mathrm{mg}, 0.101 \mathrm{mmol}$ ) and NaOMe (12 $\mathrm{mg}, 0.22 \mathrm{mmol}$ ). After work up gave $3 \mathbf{b L}_{\mathbf{1}}$ a grey yellow solid (65 mg, 92\%). ${ }^{1} \mathrm{H}$ NMR (500 MHz, DMSO, $298 \mathrm{~K}$ ): $\delta 8.96$ $\left(1 \mathrm{H}, \mathrm{d}, J=3.0 \mathrm{~Hz}, \mathrm{H}_{5 \mathrm{~A} / 5 \mathrm{~B}}\right), 8.95\left(1 \mathrm{H}, \mathrm{d}, J=3.0 \mathrm{~Hz}, \mathrm{H}_{5 \mathrm{~A} / 5 \mathrm{~B}}\right), 7.95$ $\left(1 \mathrm{H}\right.$, brd $\left., J=7.3 \mathrm{~Hz}, \mathrm{H}_{\mathrm{e}}\right), 7.90\left(1 \mathrm{H}, \mathrm{td}, J=7.3,1.2 \mathrm{~Hz}, \mathrm{H}_{\mathrm{f}}\right) 7.86$ $\left(1 \mathrm{H}, \mathrm{d}, J=8.3 \mathrm{~Hz}, \mathrm{H}_{4 \mathrm{~A} / 4 \mathrm{~B}}\right) 7.80\left(1 \mathrm{H}, \mathrm{d}, J=8.3 \mathrm{~Hz}, \mathrm{H}_{4 \mathrm{~A} / 4 \mathrm{~B}}\right) 7.70$ $\left(1 \mathrm{H}, \mathrm{d}, J=5.4 \mathrm{~Hz}, \mathrm{H}_{\mathrm{h}}\right) 7.36\left(1 \mathrm{H}, \mathrm{dd}, J=7.2,1.7 \mathrm{~Hz}, \mathrm{H}_{3 \mathrm{~A}}\right) 7.34$ $\left(1 \mathrm{H}, \mathrm{d}, J=2.0 \mathrm{~Hz}, \mathrm{H}_{\mathrm{a}}\right) 7.27\left(1 \mathrm{H}, \mathrm{dd}, J=1.4,8.4 \mathrm{~Hz}, \mathrm{H}_{3 \mathrm{~B}}\right), 7.21$ $\left(1 \mathrm{H}, \mathrm{d}, J=2.2 \mathrm{~Hz}, \mathrm{H}_{7 \mathrm{~B}}\right), 7.16\left(1 \mathrm{H}\right.$, br. $\left.\mathrm{t}, J=5.8 \mathrm{~Hz}, \mathrm{H}_{\mathrm{g}}\right), 6.81$ $\left(1 \mathrm{H}, \mathrm{d}, J=1.9 \mathrm{~Hz}, \mathrm{H}_{\mathrm{b}}\right), 6.76\left(1 \mathrm{H}\right.$, br. $\left.\mathrm{t}, J=4.0 \mathrm{~Hz}, \mathrm{H}_{6 \mathrm{~A}}\right), 6.73$ $\left(1 \mathrm{H}\right.$, br. t, $\left.J=2.0 \mathrm{~Hz}, \mathrm{H}_{6 \mathrm{~B}}\right), 6.68\left(1 \mathrm{H}, \mathrm{d}, J=2.0 \mathrm{~Hz}, \mathrm{H}_{7 \mathrm{~A}}\right), 6.51$ $\left(1 \mathrm{H}, \mathrm{d}, J=1.8 \mathrm{~Hz}, \mathrm{H}_{1 \mathrm{~A}}\right), 6.35\left(1 \mathrm{H}, \mathrm{d}, J=1.6 \mathrm{~Hz}, \mathrm{H}_{1 \mathrm{~B}}\right) .{ }^{13} \mathrm{C} \mathrm{NMR}$ $(126 \mathrm{MHz}, \mathrm{DMSO}, 298 \mathrm{~K}): \delta 155.8\left(\mathrm{C}_{\mathrm{q}}\right), 149.0\left(\mathrm{C}_{\mathrm{q}}\right), 148.9(\mathrm{CH})$, $147.1\left(\mathrm{C}_{\mathrm{q}}\right), 146.2\left(\mathrm{C}_{\mathrm{q}}\right), 139.7(\mathrm{CH}), 139.1(\mathrm{CH}), 138.9(\mathrm{CH})$, $138.3\left(\mathrm{C}_{\mathrm{q}}\right), 133.9\left(\mathrm{C}_{\mathrm{q}}\right), 129.4(\mathrm{CH}), 128.9(\mathrm{CH}), 128.9(\mathrm{CH})$, $128.5(\mathrm{CH}), 122.2(\mathrm{CH}), 120.0(\mathrm{CH}), 119.5(\mathrm{CH}), 119.0(\mathrm{CH})$, $111.9(\mathrm{CH}), 111.3(\mathrm{CH}), 108.9(\mathrm{CH}), 108.7(\mathrm{CH}), 103.6(\mathrm{CH})$, the $\mathrm{CCF}_{3}$ carbons were not identified due to low signal-to-noise ratios. ${ }^{19} \mathrm{~F}$ NMR (376 MHz, DMSO, $\left.298 \mathrm{~K}\right): \delta-61.73(\mathrm{~s}),-61.86$ (s). HRMS (ESI): $[\mathrm{M}+\mathrm{H}]^{+}, m / z 760.1267$ [760.1236 calculated for $\left.\mathrm{C}_{28} \mathrm{H}_{19} \mathrm{~F}_{6}{ }^{193} \mathrm{IrN}_{7}\right]$.

Synthesis of $\mathbf{3 b L}_{\mathbf{2}}$. This was prepared from dimer $\mathbf{1 b}(70 \mathrm{mg}$, $0.054 \mathrm{mmol}$ ), $\mathbf{H L}_{2}(24.0 \mathrm{mg}, 0.118 \mathrm{mmol})$, NaOMe $(13 \mathrm{mg}$, $0.236 \mathrm{mmol})$. After work up gave $\mathbf{3} \mathbf{b L}_{2}$ as a pale yellow solid (61 mg, 74\%). ${ }^{1} \mathrm{H}$ NMR (400 MHz, $\left.\mathrm{CDCl}_{3}, 298 \mathrm{~K}\right): \delta 8.40(1 \mathrm{H}, \mathrm{d}$, $\left.J=2.2 \mathrm{~Hz}, \mathrm{H}_{5 \mathrm{~B}}\right), 8.33\left(1 \mathrm{H}, \mathrm{d}, J=2.9 \mathrm{~Hz}, \mathrm{H}_{5 \mathrm{~A}}\right), 8.02(1 \mathrm{H}, \mathrm{br} . \mathrm{d} J=$ $\left.7.7 \mathrm{~Hz}, \mathrm{H}_{\mathrm{e}}\right), 7.97\left(1 \mathrm{H}\right.$, br. t, $\left.J=7.6 \mathrm{~Hz}, \mathrm{H}_{\mathrm{f}}\right), 7.82(1 \mathrm{H}, \mathrm{br} . \mathrm{d}, J=$ $\left.5.2 \mathrm{~Hz}, \mathrm{H}_{\mathrm{h}}\right), 7.51\left(1 \mathrm{H}, \mathrm{d}, J=7.9 \mathrm{~Hz}, \mathrm{H}_{4 \mathrm{~B}}\right), 7.46(1 \mathrm{H}, \mathrm{d}, J=8.3$ $\left.\mathrm{Hz}, \mathrm{H}_{4 \mathrm{~A}}\right), 7.25-7.21\left(2 \mathrm{H}, \mathrm{m}, \mathrm{H}_{3 \mathrm{~A}, \mathrm{~g}}\right), 7.17(1 \mathrm{H}, \mathrm{br} . \mathrm{d}, J=7.7 \mathrm{~Hz}$, $\left.\mathrm{H}_{3 \mathrm{~B}}\right), 7.02\left(1 \mathrm{H}, \mathrm{d}, J=2.1 \mathrm{~Hz}, \mathrm{H}_{7 \mathrm{~A}}\right), 6.82\left(1 \mathrm{H}, \mathrm{d}, J=2.2 \mathrm{~Hz}, \mathrm{H}_{7 \mathrm{~B}}\right)$, $6.74\left(1 \mathrm{H}, \mathrm{s}, \mathrm{H}_{\mathrm{b}}\right), 6.57\left(1 \mathrm{H}, \mathrm{t}, J=2.6 \mathrm{~Hz}, \mathrm{H}_{6 \mathrm{~A}}\right), 6.47(1 \mathrm{H}, \mathrm{t}, J=2.3$ $\left.\mathrm{Hz}, \mathrm{H}_{6 \mathrm{~B}}\right), 6.43\left(1 \mathrm{H}\right.$, br. d, $\left.J=1.2 \mathrm{~Hz}, \mathrm{H}_{1 \mathrm{~A}}\right), 6.40(1 \mathrm{H}, \mathrm{br} . \mathrm{d}, J=$ $0.6 \mathrm{~Hz}, \mathrm{H}_{1 \mathrm{~B}}$ ), $1.36\left(9 \mathrm{H}, \mathrm{s}, \mathrm{H}_{\mathrm{Bu}}^{t}\right) .{ }^{13} \mathrm{C} \mathrm{NMR}\left(125 \mathrm{MHz}, \mathrm{CDCl}_{3}\right.$, 
$298 \mathrm{~K}): \delta 160.1\left(\mathrm{C}_{\mathrm{q}}\right), 153.4\left(\mathrm{C}_{\mathrm{q}}\right), 151.3\left(\mathrm{C}_{\mathrm{q}}\right), 150.0(\mathrm{CH}), 145.8$ (q), $140.2(\mathrm{CH}), 139.3(\mathrm{CH}), 138.3(\mathrm{CH}), 132.0\left(\mathrm{C}_{\mathrm{q}}\right), 130.1(\mathrm{CH})$, $129.4(\mathrm{CH}), 129.0(\mathrm{CH}), 128.3\left(\mathrm{C}_{\mathrm{q}}\right), 128.2\left(\mathrm{C}_{\mathrm{q}}\right), 128.1(\mathrm{CH})$, $127.5\left(\mathrm{C}_{\mathrm{q}}\right), 127.3\left(\mathrm{C}_{\mathrm{q}}\right), 125.0(\mathrm{CH}), 122.1(\mathrm{CH}), 121.1(\mathrm{CH})$, $120.9(\mathrm{CH}), 112.4(\mathrm{CH}), 111.7(\mathrm{CH}), 109.1(\mathrm{CH}), 108.4(\mathrm{CH})$, $101.2\left(\mathrm{C}_{\mathrm{b}}\right), 32.0\left(\mathrm{C}_{\mathrm{i}}\right), 30.2\left(\mathrm{C}_{\mathrm{Bu}}^{t}\right)$. The $\mathrm{CCF}_{3}$ carbons were not identified due to low signal-to-noise ratios. ${ }^{19} \mathrm{~F}$ NMR (376 MHz, $\mathrm{CDCl}_{3}, 298 \mathrm{~K}$ ): $\delta-61.73$ (s), -62.00 (s). HRMS (ESI): $[\mathrm{M}+\mathrm{H}]^{+} \mathrm{m} / \mathrm{z} \quad 816.1871 \quad[816.1861 \quad$ calculated for $\left.\mathrm{C}_{32} \mathrm{H}_{27} \mathrm{~F}_{6}{ }^{193} \mathrm{IrN}_{7}\right]$.

Synthesis of $\mathbf{3 b L}_{3}$. This was prepared from dimer $\mathbf{1 b}(70 \mathrm{mg}$, $0.053 \mathrm{mmol}), \mathbf{H L}_{3}(26.2 \mathrm{mg}, 0.12 \mathrm{mmol})$ and $\mathrm{NaOMe}(12.7 \mathrm{mg}$, $0.23 \mathrm{mmol})$. After work up gave $\mathbf{3} \mathbf{b L}_{3}$ as a pale yellow solid (77 mg, 85\%). ${ }^{1} \mathrm{H}$ NMR (400 MHz, DMSO, $\left.298 \mathrm{~K}\right): \delta 8.99(1 \mathrm{H}, \mathrm{d}$, $\left.J=2.8 \mathrm{~Hz}, \mathrm{H}_{5 \mathrm{~B}}\right), 8.95\left(1 \mathrm{H}, \mathrm{d}, J=2.5 \mathrm{~Hz}, \mathrm{H}_{5 \mathrm{~A}}\right), 8.00(1 \mathrm{H}, \mathrm{br} . \mathrm{d}, J$ $\left.=8.0 \mathrm{~Hz}, \mathrm{H}_{\mathrm{e}}\right), 7.94\left(1 \mathrm{H}, \mathrm{td}, J=7.5,1.5 \mathrm{~Hz}, \mathrm{H}_{\mathrm{f}}\right), 7.86(1 \mathrm{H}, \mathrm{d}, J=$ $\left.8.2 \mathrm{~Hz}, \mathrm{H}_{4 \mathrm{~A}}\right), 7.82\left(1 \mathrm{H}, \mathrm{d}, J=8.2 \mathrm{~Hz}, \mathrm{H}_{4 \mathrm{~B}}\right), 7.71(1 \mathrm{H}, \mathrm{br} \mathrm{d}, J=$ $\left.5.0 \mathrm{~Hz}, \mathrm{H}_{\mathrm{h}}\right), 7.66-7.61\left(2 \mathrm{H}, \mathrm{m}, \mathrm{H}_{\mathrm{j}, \mathrm{k}}\right), 7.36(1 \mathrm{H}, \mathrm{dd}, J=8.5,1.5$ $\left.\mathrm{Hz}, \mathrm{H}_{3 \mathrm{~A}}\right), 7.31-7.23\left(5 \mathrm{H}, \mathrm{m}, \mathrm{H}_{3 \mathrm{~B}, 7 \mathrm{~B}, \mathrm{~b}, l, \mathrm{~m})}, 7.18\right.$ (1H, ddd, $J=6.5$, $\left.5.5,1.5 \mathrm{~Hz}, \mathrm{H}_{\mathrm{g}}\right), 7.12\left(1 \mathrm{H}, \mathrm{br} \mathrm{t}, J=7.0 \mathrm{~Hz}, \mathrm{H}_{\mathrm{n}}\right), 6.84(1 \mathrm{H}, \mathrm{d}, J=$ $\left.2.2 \mathrm{~Hz}, \mathrm{H}_{7 \mathrm{~A}}\right), 6.77\left(1 \mathrm{H}, \mathrm{t}, J=2.5 \mathrm{~Hz}, \mathrm{H}_{6 \mathrm{~B}}\right), 6.71(1 \mathrm{H}, \mathrm{t}, J=2.5$ $\left.\mathrm{Hz}, \mathrm{H}_{6 \mathrm{~A}}\right), 6.47\left(1 \mathrm{H}\right.$, br. d, $\left.J=1.5 \mathrm{~Hz}, \mathrm{H}_{1 \mathrm{~A}}\right), 6.40(1 \mathrm{H}, \mathrm{br} . \mathrm{d}, J=$ $\left.1.6 \mathrm{~Hz}, \mathrm{H}_{1 \mathrm{~B}}\right) .{ }^{13} \mathrm{C}$ NMR (126 MHz, DMSO, $\left.298 \mathrm{~K}\right): \delta 155.5\left(\mathrm{C}_{\mathrm{q}}\right)$, $152.0\left(\mathrm{C}_{\mathrm{q}}\right), 151.0\left(\mathrm{C}_{\mathrm{q}}\right), 149.0\left(\mathrm{C}_{\mathrm{h}}\right), 147.0\left(\mathrm{C}_{\mathrm{q}}\right), 146.2\left(\mathrm{C}_{\mathrm{q}}\right), 139.4$ $\left(\mathrm{C}_{\mathrm{f}}\right), 139.0\left(2 \times \mathrm{C}_{7 \mathrm{~A}, 7 \mathrm{~B}}\right), 138.2\left(\mathrm{C}_{\mathrm{q}}\right), 135.3\left(\mathrm{C}_{\mathrm{q}}\right), 133.8\left(\mathrm{C}_{\mathrm{q}}\right), 129.4$ $\left(\mathrm{C}_{5 \mathrm{~A} / \mathrm{B}}\right), 129.0\left(\mathrm{C}_{5 \mathrm{~A} / \mathrm{B}}\right), 128.8\left(\mathrm{C}_{1 \mathrm{~A} / \mathrm{B}}\right), 128.6\left(\mathrm{C}_{1 \mathrm{~A} / \mathrm{B}}\right), 128.3(2 \times$ $\left.\mathrm{C}_{l, \mathrm{~m}}\right), 125.7\left(\mathrm{C}_{\mathrm{n}}\right), 124.4\left(2 \times \mathrm{C}_{\mathrm{j} / \mathrm{k}}\right), 122.4\left(\mathrm{C}_{\mathrm{g}}\right), 120.0\left(\mathrm{C}_{3 \mathrm{~A}}\right), 119.6$ $\left(\mathrm{C}_{\mathrm{e}}\right), 119.0\left(\mathrm{C}_{3 \mathrm{~B}}\right), 111.9\left(\mathrm{C}_{4 \mathrm{~A}}\right), 111.4\left(\mathrm{C}_{4 \mathrm{~B}}\right), 109.0\left(\mathrm{C}_{6 \mathrm{~B}}\right), 108.8$ $\left(\mathrm{C}_{6 \mathrm{~A}}\right), 100.8\left(\mathrm{C}_{\mathrm{b}}\right)$. The $\mathrm{CCF}_{3}$ carbons were not identified due to low signal-to-noise ratios. ${ }^{19} \mathrm{~F}$ NMR (376 MHz, DMSO, $\left.298 \mathrm{~K}\right): \delta$ -60.24 (s), -60.37 (s). HRMS (ESI): $[\mathrm{M}+\mathrm{H}]^{+}, \mathrm{m} / z 836.1589$ [836.1549 calculated for $\mathrm{C}_{34} \mathrm{H}_{23} \mathrm{~F}_{6}{ }^{193} \mathrm{IrN}_{7}$ ].

Synthesis of $\mathbf{2 C H L}_{\mathbf{1}}$. This was prepared from dimer $\mathbf{1 c}$ (50 mg, $0.048 \mathrm{mmol}$ ), $\mathbf{H L}_{\mathbf{1}}$ (16 mg, 0.10) and $\mathrm{KPF}_{6}(21.5 \mathrm{mg}$, $0.12 \mathrm{mmol})$ in $\mathrm{MeOH}(3 \mathrm{ml})$ were heated in a microwave irradiation for $40 \mathrm{~min}$. After work up, the product was isolated as an yellow solid (53 mg, 72\%). ${ }^{1} \mathrm{H}$ NMR (500 $\mathrm{MHz}, \mathrm{CD}_{3} \mathrm{CN}$, $298 \mathrm{~K}): \delta 8.20\left(1 \mathrm{H}, \mathrm{dt}, J=7.8,1.1 \mathrm{~Hz}, \mathrm{H}_{\mathrm{e}}\right), 8.08(1 \mathrm{H}, \mathrm{d}, J=8.09$ $\left.\mathrm{Hz}, \mathrm{H}_{5 \mathrm{~B}}\right), 8.05\left(2 \mathrm{H}, \mathrm{m}, \mathrm{H}_{5 \mathrm{~A}, \mathrm{f}}\right), 7.90-7.86\left(2 \mathrm{H}, \mathrm{m}, \mathrm{H}_{6 \mathrm{~A}, 6 \mathrm{~B}}\right), 7.84$ $\left(1 \mathrm{H}, \mathrm{ddd}, J=6.0,1.5,0.9 \mathrm{~Hz}, \mathrm{H}_{\mathrm{h}}\right), 7.81\left(1 \mathrm{H}, \mathrm{d}, J=1.1 \mathrm{~Hz}, \mathrm{H}_{4 \mathrm{~A}}\right)$, 7.79-7.78 (2H, m, $\left.\mathrm{H}_{4 \mathrm{~B}, \mathrm{a}}\right), 7.66(1 \mathrm{H}, \mathrm{ddd}, J=5.9,1.5,0.7 \mathrm{~Hz}$, $\left.\mathrm{H}_{8 \mathrm{~B}}\right), 7.61\left(1 \mathrm{H}, \mathrm{ddd}, J=5.8,1.4,0.7 \mathrm{~Hz}, \mathrm{H}_{8 \mathrm{~A}}\right), 7.35(1 \mathrm{H}, \mathrm{ddd}, J=$ $\left.7.6,5.5,1.4 \mathrm{~Hz}, \mathrm{H}_{\mathrm{g}}\right), 7.18\left(1 \mathrm{H}, \mathrm{d}, J=2.7 \mathrm{~Hz}, \mathrm{H}_{\mathrm{b}}\right), 7.11-7.01(4 \mathrm{H}$,

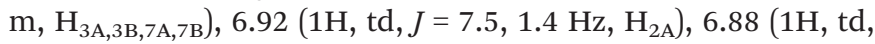
$\left.J=7.4,1.3 \mathrm{~Hz}, \mathrm{H}_{2 \mathrm{~B}}\right), 6.32\left(1 \mathrm{H}, \mathrm{dd}, J=7.6,0.6 \mathrm{~Hz}, \mathrm{H}_{1 \mathrm{~B}}\right), 6.29$ $\left(1 \mathrm{H}, \mathrm{dd}, J=7.6,0.7 \mathrm{~Hz}, \mathrm{H}_{1 \mathrm{~A}}\right) .{ }^{13} \mathrm{C} \mathrm{NMR}\left(125 \mathrm{MHz}, \mathrm{CD}_{3} \mathrm{CN}\right.$, $298 \mathrm{~K}): \delta 168.8\left(\mathrm{C}_{\mathrm{q}}\right), 168.4\left(\mathrm{C}_{\mathrm{q}}\right), 153.2\left(\mathrm{C}_{\mathrm{q}}\right), 153.0\left(\mathrm{C}_{\mathrm{q}}\right), 151.3$ $\left(\mathrm{C}_{\mathrm{h}}\right), 150.8\left(\mathrm{C}_{\mathrm{q}}\right), 150.7\left(\mathrm{C}_{8 \mathrm{~A}}\right), 150.4\left(\mathrm{C}_{8 \mathrm{~B}}\right), 147.1\left(\mathrm{C}_{\mathrm{q}}\right), 145.7\left(\mathrm{C}_{\mathrm{q}}\right)$, $145.5\left(\mathrm{C}_{\mathrm{q}}\right), 140.5\left(\mathrm{C}_{\mathrm{f}}\right), 139.5\left(\mathrm{C}_{6 \mathrm{~A} / 6 \mathrm{~B}}\right), 139.4\left(\mathrm{C}_{6 \mathrm{~A} / 6 \mathrm{~B}}\right), 135.0\left(\mathrm{C}_{\mathrm{a}}\right)$, $133.3\left(\mathrm{C}_{1 \mathrm{~A}}\right), 132.5\left(\mathrm{C}_{1 \mathrm{~B}}\right), 131.3\left(\mathrm{C}_{2 \mathrm{~B}}\right), 130.8\left(\mathrm{C}_{2 \mathrm{~A}}\right), 127.4\left(\mathrm{C}_{\mathrm{g}}\right)$, $125.8\left(\mathrm{C}_{4 \mathrm{~A}}\right), 125.6\left(\mathrm{C}_{4 \mathrm{~B}}\right), 124.6\left(\mathrm{C}_{\mathrm{e}}\right), 124.3\left(\mathrm{C}_{3 \mathrm{~A} / 3 \mathrm{~B} / 7 \mathrm{~A} / 7 \mathrm{~B}}\right), 124.0$ $\left(\mathrm{C}_{3 \mathrm{~A} / 3 \mathrm{~B} / 7 \mathrm{~A} / 7 \mathrm{~B}}\right), 123.6\left(\mathrm{C}_{3 \mathrm{~A} / 3 \mathrm{~B} / 7 \mathrm{~A} / 7 \mathrm{~B}}\right), 123.4\left(\mathrm{C}_{3 \mathrm{~A} / 3 \mathrm{~B} / 7 \mathrm{~A} / 7 \mathrm{~B}}\right), 120.7$ $\left(\mathrm{C}_{5 \mathrm{~A}}\right), 120.5\left(\mathrm{C}_{5 \mathrm{~B}}\right), 106.4\left(\mathrm{C}_{\mathrm{b}}\right)$. HRMS (ASAP): $\mathrm{m} / \mathrm{z} 646.1584$ [646.1583 calculated for $\left[\mathrm{C}_{30} \mathrm{H}_{23}{ }^{193} \mathrm{IrN}_{5}\right]$.

Synthesis of $\mathbf{2} \mathbf{c H L}_{2}$. This was prepared from dimer $\mathbf{1 c}$ (50 mg, $0.046 \mathrm{mmol}), \mathbf{H L}_{2}(21 \mathrm{mg}, 0.10)$ and $\mathrm{KPF}_{6}(21 \mathrm{mg}$,
$0.11 \mathrm{mmol})$ in $\mathrm{MeOH}(3 \mathrm{ml})$. After work up, the compound was isolated as a yellow solid (73 mg, 92\%). ${ }^{1} \mathrm{H}$ NMR $\left(500 \mathrm{MHz}, \mathrm{CD}_{3} \mathrm{CN}, 300 \mathrm{~K}\right): \delta 8.15\left(1 \mathrm{H}, \mathrm{dt}, J=7.9,0.8 \mathrm{~Hz}, \mathrm{H}_{\mathrm{e}}\right)$, $8.09\left(1 \mathrm{H}, \mathrm{tt}, J=7.9,0.8 \mathrm{~Hz}, \mathrm{H}_{5 \mathrm{~B}}\right), 8.06-8.01\left(2 \mathrm{H}, \mathrm{m}, \mathrm{H}_{5 \mathrm{~A}, \mathrm{f}}\right), 7.91$ $7.84\left(2 \mathrm{H}, \mathrm{m}, \mathrm{H}_{6 \mathrm{~A}, 6 \mathrm{~B}}\right), 7.81-7.76\left(2 \mathrm{H}, \mathrm{m}, \mathrm{H}_{\mathrm{h}, 4 \mathrm{~B}}\right), 7.77(1 \mathrm{H}, \mathrm{d}, J=$ $\left.7.6 \mathrm{~Hz}, \mathrm{H}_{4 \mathrm{~A}}\right), 7.65\left(1 \mathrm{H}\right.$, br. d, $\left.J=5.8, \mathrm{~Hz}, \mathrm{H}_{8 \mathrm{~B}}\right), 7.58(1 \mathrm{H}, \mathrm{br} . \mathrm{d}, J$ $\left.=5.8 \mathrm{~Hz}, \mathrm{H}_{8 \mathrm{~A}}\right), 7.33\left(1 \mathrm{H}\right.$, br. $\left.\mathrm{t}, J=6.6 \mathrm{~Hz}, \mathrm{H}_{\mathrm{g}}\right), 7.13-7.11(1 \mathrm{H}$, $\left.\mathrm{m}, \mathrm{H}_{7 \mathrm{~A}}\right), 7.09-6.99\left(4 \mathrm{H}, \mathrm{m}, \mathrm{H}_{3 \mathrm{~A}, 3 \mathrm{~B}, 7 \mathrm{~B}, \mathrm{~b}}\right), 6.91$ (1H, td, $J=7.4,1.2$ $\left.\mathrm{Hz}, \mathrm{H}_{2 \mathrm{~A}}\right), 6.87\left(1 \mathrm{H}, \mathrm{td}, J=7.4,1.1 \mathrm{~Hz}, \mathrm{H}_{2 \mathrm{~B}}\right), 6.30(1 \mathrm{H}, \mathrm{dd}, J=$ 7.6, $0.8 \mathrm{~Hz}, \mathrm{H}_{1 \mathrm{~B}}$ ), $6.23\left(1 \mathrm{H}, \mathrm{dd}, J=7.5,0.8 \mathrm{~Hz}, \mathrm{H}_{1 \mathrm{~A}}\right), 1.34(9 \mathrm{H}, \mathrm{s}$, $\left.\mathrm{H}_{\mathrm{Bu}}^{t}\right) \cdot{ }^{13} \mathrm{C}$ NMR: (125 MHz, $\left.\mathrm{CD}_{3} \mathrm{CN}, 298 \mathrm{~K}\right): \delta 169.3\left(\mathrm{C}_{\mathrm{q}}\right), 168.6$ $\left(\mathrm{C}_{\mathrm{q}}\right), 160.4\left(\mathrm{C}_{\mathrm{q}}\right), 153.6\left(\mathrm{C}_{\mathrm{q}}\right), 153.4\left(\mathrm{C}_{\mathrm{q}}\right), 151.4\left(\mathrm{C}_{\mathrm{h}}\right), 151.0\left(\mathrm{C}_{8 \mathrm{~A}}\right)$, $150.7\left(\mathrm{C}_{8 \mathrm{~B}}\right), 150.0\left(\mathrm{C}_{\mathrm{q}}\right), 148.0\left(\mathrm{C}_{\mathrm{q}}\right), 146.1\left(\mathrm{C}_{\mathrm{q}}\right), 146.0\left(\mathrm{C}_{\mathrm{q}}\right), 141.0$ $\left(\mathrm{C}_{\mathrm{f}}\right), 139.8\left(\mathrm{C}_{6 \mathrm{~A} / 6 \mathrm{~B}}\right), 139.7\left(\mathrm{C}_{6 \mathrm{~A} / 6 \mathrm{~B}}\right), 134.0\left(\mathrm{C}_{1 \mathrm{~B}}\right), 132.6\left(\mathrm{C}_{1 \mathrm{~A}}\right)$, $131.7\left(\mathrm{C}_{2 \mathrm{~A}}\right), 131.1\left(\mathrm{C}_{2 \mathrm{~B}}\right), 127.8\left(\mathrm{C}_{\mathrm{g}}\right), 126.1\left(\mathrm{C}_{4 \mathrm{~A} / 4 \mathrm{~B}}\right), 126.0$ $\left(\mathrm{C}_{4 \mathrm{~A} / 4 \mathrm{~B}}\right), \quad 125.0 \quad\left(\mathrm{C}_{7 \mathrm{~A}}\right), 124.6 \quad\left(\mathrm{C}_{3 \mathrm{~A} / 3 \mathrm{~B} / 7 \mathrm{~B}}\right), 124.2 \quad\left(\mathrm{C}_{\mathrm{e}}\right), 124.0$ $\left(\mathrm{C}_{3 \mathrm{~A} / 3 \mathrm{~B} / 7 \mathrm{~B}}\right), 123.7\left(\mathrm{C}_{3 \mathrm{~A} / 3 \mathrm{~B} / 7 \mathrm{~B}}\right), 121.1\left(\mathrm{C}_{5 \mathrm{~A}}\right), 120.8\left(\mathrm{C}_{5 \mathrm{~B}}\right), 103.5\left(\mathrm{C}_{\mathrm{b}}\right)$, $32.9\left(\mathrm{C}_{\mathrm{i}}\right), 30.7\left(\mathrm{C}_{\mathrm{Bu}}^{t}\right)$. HRMS (ASAP): $m / z$ 702.2244 [702.2209 calculated for $\left.\mathrm{C}_{34} \mathrm{H}_{31}{ }^{193} \mathrm{IrN}_{5}\right]$.

Synthesis of $2 \mathbf{c H L}_{3}$. This was prepared from dimer $\mathbf{1 c}$ (50 mg, $0.046 \mathrm{mmol}$ ), $\mathbf{H L}_{3}(23.5 \mathrm{mg}, 0.10)$ and $\mathrm{KPF}_{6}(20.4 \mathrm{mg}$, $0.11 \mathrm{mmol}$ ) in $\mathrm{MeOH}(3 \mathrm{ml})$. After work up, the compound was isolated as a yellow solid (68 mg, 84\%). ${ }^{1} \mathrm{H} \quad \mathrm{NMR}$ $\left(500 \mathrm{MHz}, \mathrm{CD}_{3} \mathrm{CN}, 298 \mathrm{~K}\right): \delta 8.23\left(1 \mathrm{H}, \mathrm{dt}, J=7.8,1.1 \mathrm{~Hz}, \mathrm{H}_{\mathrm{e}}\right)$, 8.11-8.09 (1H, m, $\left.\mathrm{H}_{5 \mathrm{~B}}\right), 8.08-8.06\left(1 \mathrm{H}, \mathrm{m}, \mathrm{H}_{\mathrm{f}}\right), 8.05(1 \mathrm{H}, \mathrm{dd}, J=$ $\left.1.2 \mathrm{~Hz}, \mathrm{H}_{5 \mathrm{~A}}\right), 7.89-7.85\left(3 \mathrm{H}, \mathrm{m}, \mathrm{H}_{6 \mathrm{~A}, 6 \mathrm{~B}, 8 \mathrm{~A}}\right), 7.83(1 \mathrm{H}, \mathrm{ddd}, J=5$, $\left.1.6,0.8 \mathrm{~Hz}, \mathrm{H}_{\mathrm{h}}\right), 7.82-7.78\left(2 \mathrm{H}, \mathrm{m}, \mathrm{H}_{4 \mathrm{~A}, 4 \mathrm{~B}}\right), 7.72-7.71(2 \mathrm{H}, \mathrm{m}$, $\left.\mathrm{H}_{\mathrm{j} / \mathrm{k}}\right), 7.68\left(1 \mathrm{H}, \mathrm{ddd}, J=5.9,1.4,0.63 \mathrm{~Hz}, \mathrm{H}_{8 \mathrm{~B}}\right), 7.52\left(1 \mathrm{H}, \mathrm{s}, \mathrm{H}_{\mathrm{b}}\right)$, $7.52-7.46\left(3 \mathrm{H}, \mathrm{m}, \mathrm{H}_{l, \mathrm{~m}, \mathrm{n}}\right), 7.36(1 \mathrm{H}, \mathrm{ddd}, J=7.6,5.5,1.4 \mathrm{~Hz}$, $\left.\mathrm{H}_{\mathrm{g}}\right), 7,13-7.01\left(4 \mathrm{H}, \mathrm{m}, \mathrm{H}_{3 \mathrm{~A}, 3 \mathrm{~B}, 7 \mathrm{~A}, 7 \mathrm{~B}}\right), 6.93+6.90(2 \mathrm{H}, 2 \times \mathrm{td}, J=$ 7.6, $\left.0.9 \mathrm{~Hz}, \mathrm{H}_{2 \mathrm{~A}, 2 \mathrm{~B}}\right), 6.35\left(1 \mathrm{H}, \mathrm{dd}, J=7.6,0.9 \mathrm{~Hz}, \mathrm{H}_{1 \mathrm{~A}}\right), 6.27$ $\left(1 \mathrm{H}\right.$, dd $\left.J=7.6,0.8 \mathrm{~Hz}, \mathrm{H}_{1 \mathrm{~B}}\right) \cdot{ }^{13} \mathrm{C} \mathrm{NMR}\left(125 \mathrm{MHz}, \mathrm{CD}_{3} \mathrm{CN}\right.$, $298 \mathrm{~K}): \delta 169.0\left(\mathrm{C}_{\mathrm{q}}\right), 168.2\left(\mathrm{C}_{\mathrm{q}}\right), 154.3\left(\mathrm{C}_{\mathrm{q}}\right), 152.8\left(\mathrm{C}_{\mathrm{q}}\right), 151.2$ $\left(\mathrm{C}_{8 \mathrm{~A} / \mathrm{h}}\right), 151.1\left(\mathrm{C}_{8 \mathrm{~A} / \mathrm{h}}\right), 150.4\left(\mathrm{C}_{8 \mathrm{~B}}\right), 150.3\left(\mathrm{C}_{\mathrm{q}}\right), 149.3\left(\mathrm{C}_{\mathrm{q}}\right), 147.5$ $\left(\mathrm{C}_{\mathrm{q}}\right), 146.0\left(\mathrm{C}_{\mathrm{q}}\right), 145.5\left(\mathrm{C}_{\mathrm{q}}\right), 140.6\left(\mathrm{C}_{5 \mathrm{~B}}\right), 140.4\left(\mathrm{C}_{5 \mathrm{~A}}\right), 139.5$ $\left(\mathrm{C}_{6 \mathrm{~A} / 6 \mathrm{~B}}\right), 139.4\left(\mathrm{C}_{6 \mathrm{~A} / 6 \mathrm{~B}}\right), 133.5\left(\mathrm{C}_{1 \mathrm{~B}}\right), 132.4\left(\mathrm{C}_{1 \mathrm{~A}}\right), 131.3\left(\mathrm{C}_{2 \mathrm{~A} / 2 \mathrm{~B}}\right)$, $131.5\left(\mathrm{C}_{2 \mathrm{~A} / 2 \mathrm{~B}}\right), 131.9\left(\mathrm{C}_{l / \mathrm{m} / \mathrm{n}}\right), 130.7\left(\mathrm{C}_{l / \mathrm{m} / \mathrm{n}}\right), 130.2\left(\mathrm{C}_{\mathrm{j} / \mathrm{k}}\right), 128.6$ $\left(\mathrm{C}_{\mathrm{q}}\right), 127.6\left(\mathrm{C}_{l / \mathrm{m} / \mathrm{n}}\right), 127.5\left(\mathrm{C}_{\mathrm{g}}\right), 125.8\left(\mathrm{C}_{4 \mathrm{~A} / 4 \mathrm{~B}}\right), 125.6\left(\mathrm{C}_{4 \mathrm{~A} / 4 \mathrm{~B}}\right)$, $124.6\left(\mathrm{C}_{\mathrm{j} / \mathrm{k}}\right), 124.3\left(\mathrm{C}_{\mathrm{f}}\right), 124.0\left(\mathrm{C}_{\mathrm{e}}\right), 123.6\left(\mathrm{C}_{3 \mathrm{~A} / 3 \mathrm{~B} / 7 \mathrm{~A} / 7 \mathrm{~B}}\right), 123.4$ $\left(\mathrm{C}_{3 \mathrm{~A} / 3 \mathrm{~B} / 7 \mathrm{~A} / 7 \mathrm{~B}}\right), 120.7\left(\mathrm{C}_{3 \mathrm{~A} / 3 \mathrm{~B} / 7 \mathrm{~A} / 7 \mathrm{~B}}\right), 120.5\left(\mathrm{C}_{3 \mathrm{~A} / 3 \mathrm{~B} / 7 \mathrm{~A} / 7 \mathrm{~B}}\right), 104.2\left(\mathrm{C}_{\mathrm{b}}\right)$.

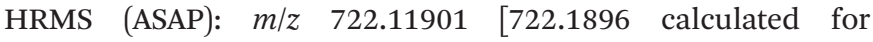
$\left.\mathrm{C}_{36} \mathrm{H}_{27}{ }^{193} \mathrm{IrN}_{5}\right]$.

Synthesis of $3 \mathbf{C L}_{1}$. This was prepared from dimer 1 c (50 mg, $0.046 \mathrm{mmol}$ ), $\mathbf{H L}_{\mathbf{1}}(15 \mathrm{mg}, 0.10 \mathrm{mmol})$ and NaOMe (6 mg, $0.10 \mathrm{mmol})$ in $\mathrm{MeOH}(3 \mathrm{~mL})$ and DCM $(6 \mathrm{ml})$. After work up, the compound was isolated as grey yellow solid (50 $\mathrm{mg}, 83 \%$ ). ${ }^{1} \mathrm{H}$ NMR (500 MHz, $\left.\mathrm{CD}_{2} \mathrm{Cl}_{2}, 298 \mathrm{~K}\right): \delta 7.80(1 \mathrm{H}, \mathrm{bd}, J=8.0 \mathrm{~Hz}$, $\left.\mathrm{H}_{5 \mathrm{~B}}\right), 7.76\left(1 \mathrm{H}, \mathrm{bd}, J=8.0 \mathrm{~Hz}, \mathrm{H}_{5 \mathrm{~A}}\right), 7.73(1 \mathrm{H}, \mathrm{dt}, J=7.9,1.1 \mathrm{~Hz}$, $\left.\mathrm{H}_{\mathrm{e}}\right), 7.66\left(1 \mathrm{H}, \mathrm{dd}, J=7.5,1.6 \mathrm{~Hz}, \mathrm{H}_{\mathrm{f}}\right), 7.64\left(1 \mathrm{H}, \mathrm{m}, \mathrm{H}_{\mathrm{h}}\right)$, $7.60-7.56\left(4 \mathrm{H}, \mathrm{m}, \mathrm{H}_{4 \mathrm{~A}, 4 \mathrm{~B}, 6 \mathrm{~A}, 6 \mathrm{~B}}\right), 7.52(1 \mathrm{H}, \mathrm{dd}, J=5.8,0.7 \mathrm{~Hz}$, $\left.\mathrm{H}_{8 \mathrm{~B}}\right), 7.47\left(1 \mathrm{H}, \mathrm{m}, \mathrm{H}_{8 \mathrm{~A}}\right), 7.46\left(1 \mathrm{H}, \mathrm{d}, J=1.9 \mathrm{~Hz}, \mathrm{H}_{\mathrm{a}}\right), 6.92-6.90$ $\left(1 \mathrm{H}, \mathrm{m}, \mathrm{H}_{\mathrm{g}}\right), 6.89-6.87\left(1 \mathrm{H}, \mathrm{m}, \mathrm{H}_{3 \mathrm{~B}}\right), 6.86-6.78(4 \mathrm{H}, \mathrm{m}$,

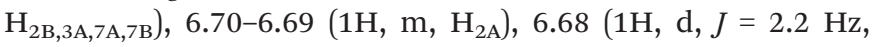
$\left.\mathrm{H}_{\mathrm{b}}\right), 6.27\left(1 \mathrm{H}, \mathrm{dd}, J=7.5,0.8 \mathrm{~Hz}, \mathrm{H}_{1 \mathrm{~B}}\right), 6.23(1 \mathrm{H}, \mathrm{dd}, J=7.5,0.8$ $\left.\mathrm{Hz}, \mathrm{H}_{1 \mathrm{~A}}\right) \cdot{ }^{13} \mathrm{C}$ NMR $\left(125 \mathrm{MHz}, \mathrm{CD}_{2} \mathrm{Cl}_{2}, 298 \mathrm{~K}\right): \delta 168.8\left(\mathrm{C}_{\mathrm{q}}\right)$, $168.4\left(\mathrm{C}_{\mathrm{q}}\right), 155.5\left(\mathrm{C}_{\mathrm{q}}\right), 154.5\left(\mathrm{C}_{\mathrm{q}}\right), 150.5\left(\mathrm{C}_{\mathrm{q}}\right), 150.4\left(\mathrm{C}_{\mathrm{h}}\right), 150.1$ 
$\left(\mathrm{C}_{8 \mathrm{~B}}\right), 148.9\left(\mathrm{C}_{8 \mathrm{~A}}\right), 145.1\left(\mathrm{C}_{\mathrm{q}}\right), 144.2\left(\mathrm{C}_{\mathrm{q}}\right), 139.3\left(\mathrm{C}_{\mathrm{a}}\right), 138.4\left(\mathrm{C}_{\mathrm{f}}\right)$, $137.5\left(\mathrm{C}_{6 \mathrm{~A} / 6 \mathrm{~B}}\right), 137.2\left(\mathrm{C}_{6 \mathrm{~A} / 6 \mathrm{~B}}\right), 132.4\left(\mathrm{C}_{1 \mathrm{~B}}\right), 132.3\left(\mathrm{C}_{1 \mathrm{~A}}\right), 130.5$ $\left(\mathrm{C}_{2 \mathrm{~B}}\right), 130.0\left(\mathrm{C}_{2 \mathrm{~A}}\right), 124.8\left(\mathrm{C}_{4 \mathrm{~A} / 4 \mathrm{~B}}\right), 124.6\left(\mathrm{C}_{4 \mathrm{~A} / 4 \mathrm{~B}}\right), 123.3\left(\mathrm{C}_{3 \mathrm{~B}}\right)$, $123.2\left(\mathrm{C}_{3 \mathrm{~A} / 7 \mathrm{~A} / 7 \mathrm{~B}}\right), 122.6\left(\mathrm{C}_{\mathrm{g}}\right), 122.1\left(\mathrm{C}_{3 \mathrm{~A} / 7 \mathrm{~A} / 7 \mathrm{~B}}\right), 121.7\left(\mathrm{C}_{3 \mathrm{~A} / 7 \mathrm{~A} / 7 \mathrm{~B}}\right)$, $120.7\left(\mathrm{C}_{\mathrm{e}}\right), 119.5\left(\mathrm{C}_{5 \mathrm{~B}}\right), 119.3\left(\mathrm{C}_{5 \mathrm{~A}}\right), 104.1\left(\mathrm{C}_{\mathrm{b}}\right)$. HRMS (ASAP): $[\mathrm{M}+\mathrm{H}]^{+} \mathrm{m} / \mathrm{z} 646.1578$ [656.1583 calculated for $\left.\mathrm{C}_{30} \mathrm{H}_{23}{ }^{193} \mathrm{IrN}_{5}\right]$.

Synthesis of $\mathbf{3 C L}_{2}$. This was prepared from the $2.15 \mathrm{c}(75 \mathrm{mg}$, $0.070 \mathrm{mmol}$ ), $\mathbf{H L}_{2}(31 \mathrm{mg}, 0.15 \mathrm{mmol}$ ) and NaOMe (30 mg, $0.154 \mathrm{mmol}$ ) in $\mathrm{MeOH} / \mathrm{DCM}(3: 6 \mathrm{ml})$. After work up, the compound was isolated as yellow solid (72 mg, 73\%). For the ${ }^{1} \mathrm{H}$ NMR spectrum assignments are given where possible but there are many overlapping peaks. ${ }^{1} \mathrm{H} \mathrm{NMR}\left(500 \mathrm{MHz}, \mathrm{CDCl}_{3}\right.$, $300 \mathrm{~K}): \delta 7.83-7.80(3 \mathrm{H}, \mathrm{m}), 7.74\left(1 \mathrm{H}, \mathrm{td}, J=7.7,1.3 \mathrm{~Hz}, \mathrm{H}_{\mathrm{f}}\right)$, 7.66-7.58 (6H, m), 7.51 (1H, m), 6.99-6.93 (4H, m, $3 \times \mathrm{Ph}, \mathrm{H}_{\mathrm{g}}$ ), 6.87-6.84 (3H, m), $6.61\left(1 \mathrm{H}, \mathrm{s}, \mathrm{H}_{\mathrm{b}}\right), 6.35(1 \mathrm{H}, \mathrm{dd}, J=7.5,0.5$ $\mathrm{Hz}, \mathrm{H}_{1 \mathrm{~B}}$ ), 6.27 (1H, dd, $\left.J=7.5,0.8 \mathrm{~Hz}, \mathrm{H}_{1 \mathrm{~A}}\right), 1.29\left(9 \mathrm{H}, \mathrm{s}, \mathrm{H}_{\mathrm{Bu}}^{t}\right)$. ${ }^{13} \mathrm{C}$ NMR (100 MHz, $\left.\mathrm{CDCl}_{3}, 300 \mathrm{~K}\right): \delta 168.4\left(\mathrm{C}_{\mathrm{q}}\right), 167.8\left(\mathrm{C}_{\mathrm{q}}\right)$, $150.4(\mathrm{CH}), 149.7\left(\mathrm{C}_{\mathrm{q}}\right), 149.5(\mathrm{CH}), 148.3(\mathrm{CH}), 144.5\left(\mathrm{C}_{\mathrm{q}}\right)$, $144.0\left(\mathrm{C}_{\mathrm{q}}\right), 138.0(\mathrm{CH}), 137.0(\mathrm{CH}), 136.7(\mathrm{CH}), 132.3(\mathrm{CH})$, $131.9(\mathrm{CH}), 130.2(\mathrm{CH}), 129.8(\mathrm{CH}), 124.4(\mathrm{CH}), 124.3(\mathrm{CH})$, $123.0(\mathrm{CH}), 122.9(\mathrm{CH} 122.1(\mathrm{CH}), 121.8(\mathrm{CH}), 121.6(\mathrm{CH})$, $120.5(\mathrm{CH}), 119.2(\mathrm{CH}), 118.7(\mathrm{CH}), 100.3\left(\mathrm{C}_{\mathrm{b}}\right), 30.7\left(\mathrm{C}_{\mathrm{Bu}}^{t}\right)$. The quaternary carbon of the ${ }^{t} \mathrm{Bu}$ was not observed. HRMS (ASAP): $[\mathrm{M}+\mathrm{H}]^{+}, m / z 702.2236$ [702.2209 calculated for $\left.\mathrm{C}_{34} \mathrm{H}_{31}{ }^{193} \mathrm{IrN}_{5}\right]$.

Synthesis of $\mathbf{3 c L}_{3}$. This was prepared from dimer $1 \mathrm{c}(50 \mathrm{mg}$, $0.046 \mathrm{mmol}), \mathbf{H L}_{3}(23 \mathrm{mg}, 0.10 \mathrm{mmol})$ and NaOMe $(6 \mathrm{mg}$, $0.10 \mathrm{mmol}$ ) in $\mathrm{MeOH} / \mathrm{DCM}(3: 6 \mathrm{ml})$. After work up, the product was isolated as yellow solid (50 mg, 87\%). The ${ }^{1} \mathrm{H}$ NMR spectrum for this complex is very complicated with a lot of overlapping signals hence very few assignments are given. ${ }^{1} \mathrm{H}$ NMR (500 MHz, $\left.\mathrm{CDCl}_{3}, 298 \mathrm{~K}\right): \delta 7.83(1 \mathrm{H}, \mathrm{bd}, J=5.5 \mathrm{~Hz})$, 7.80-7.68 (5H, m), 7.66-7.52 (6H m), $7.45(1 \mathrm{H}, \mathrm{td}, J=7.2,1.1$ $\mathrm{Hz}$ ), 7.24 (2H, t, $J=7.6 \mathrm{~Hz}), 7.11(1 \mathrm{H}$, br. t, $J=7.4 \mathrm{~Hz}), 7.01$ $\left(1 \mathrm{H}, \mathrm{s}, \mathrm{H}_{\mathrm{b}}\right), 6.956 .78(6 \mathrm{H}, \mathrm{m}), 6.75(1 \mathrm{H}, \mathrm{td}, J=6.1,0.9 \mathrm{~Hz})$, $6.39\left(1 \mathrm{H}, \mathrm{bd}, J=7.3 \mathrm{~Hz}, \mathrm{H}_{1 \mathrm{~B}}\right), 6.33\left(1 \mathrm{H}, \mathrm{bd}, J=7.2 \mathrm{~Hz}, \mathrm{H}_{1 \mathrm{~A}}\right)$. Due to overlap no assignments are made ${ }^{13} \mathrm{C}$ NMR $(126 \mathrm{MHz}$, $\left.\mathrm{CDCl}_{3}, 298 \mathrm{~K}\right): \delta$ ppm $168.6\left(\mathrm{C}_{\mathrm{q}}\right), 168.1\left(\mathrm{C}_{\mathrm{q}}\right), 155.7\left(\mathrm{C}_{\mathrm{q}}\right), 155.1$ $\left(\mathrm{C}_{\mathrm{q}}\right), 153.4\left(\mathrm{C}_{\mathrm{q}}\right), 151.0\left(\mathrm{C}_{\mathrm{q}}\right), 150.6\left(\mathrm{C}_{\mathrm{q}}\right), 150.4(\mathrm{CH}), 149.4(\mathrm{CH})$, $148.2(\mathrm{CH}), 144.6\left(\mathrm{C}_{\mathrm{q}}\right), 143.7\left(\mathrm{C}_{\mathrm{q}}\right), 137.5(\mathrm{CH}) 136.7(\mathrm{CH}) 136.3$ $(\mathrm{CH}) 134.6\left(\mathrm{C}_{\mathrm{q}}\right), 132.1(\mathrm{CH}), 132.0(\mathrm{CH}), 130.1(\mathrm{CH}), 129.5$ $(\mathrm{CH}), 128.3(2 \times \mathrm{CH}), 126.2(\mathrm{CH}), 125.4(2 \times \mathrm{CH}), 124.2(\mathrm{CH})$, $124.1(\mathrm{CH}), 122.6(\mathrm{CH}), 122.0(\mathrm{CH}), 121.8(\mathrm{CH}), 121.4(\mathrm{CH})$, $120.9(\mathrm{CH}), 119.6(\mathrm{CH}), 119.0(\mathrm{CH}), 118.4(\mathrm{CH}), 100.9(\mathrm{CH})$. HRMS (ASAP): $[\mathrm{M}+\mathrm{H}]^{+}, m / z 722.1862$ [722.1896 calculated for $\mathrm{C}_{36} \mathrm{H}_{27}{ }^{193} \mathrm{IrN}_{5}$.

Synthesis of $3 \mathbf{d L}_{2}$. This complex was prepared from the dimer 1d (70 mg, $0.053 \mathrm{mmol}), \mathbf{H L}_{2}(23.0 \mathrm{mg}, 0.114 \mathrm{mmol})$ and NaOMe (13.6 mg, $0.252 \mathrm{mmol})$. After work $\mathbf{3} \mathbf{d L}_{2}$ was isolated as a yellow solid (66 mg, 76\%). ${ }^{1} \mathrm{H}$ NMR $(500 \mathrm{MHz}$, $\left.\mathrm{CD}_{2} \mathrm{Cl}_{2}, 298 \mathrm{~K}\right): \delta$ ppm $7.98\left(1 \mathrm{H}\right.$, br d, $\left.J=7.9 \mathrm{H}_{5 \mathrm{~A} / 5 \mathrm{~B}}\right) 7.90(1 \mathrm{H}$, br d, $\left.J=8.1 \mathrm{~Hz}, \mathrm{H}_{5 \mathrm{~A} / 5 \mathrm{~B}}\right) 7.80-7.70\left(5 \mathrm{H}, \mathrm{m}, \mathrm{H}_{4 \mathrm{~A}, 4 \mathrm{~B}, 6 \mathrm{~A}, 6 \mathrm{~B}, 8 \mathrm{~B}}\right)$ $7.70-7.65\left(2 \mathrm{H}, \mathrm{m}, \mathrm{H}_{\mathrm{e}, \mathrm{f}}\right) 7.54\left(1 \mathrm{H}, \mathrm{d}, J=5.5 \mathrm{~Hz}, \mathrm{H}_{\mathrm{h}}\right) 7.49(1 \mathrm{H}, \mathrm{d}$, $\left.J=6.2 \mathrm{~Hz}, \mathrm{H}_{8 \mathrm{~A}}\right) 7.23\left(1 \mathrm{H}, \mathrm{dd}, J=1.2,8.2 \mathrm{~Hz}, \mathrm{H}_{3 \mathrm{~A}}\right), 7.18(1 \mathrm{H}, \mathrm{dd}$, $\left.J=1.2,8.1 \mathrm{~Hz}, \mathrm{H}_{3 \mathrm{~B}}\right), 6.89-6.81\left(2 \mathrm{H}, \mathrm{m}, \mathrm{H}_{7 \mathrm{~A}, 7 \mathrm{~B}}\right), 6.86(1 \mathrm{H}, \mathrm{td}, J=$ 5.7, $2.9 \mathrm{~Hz}, \mathrm{H}_{\mathrm{g}}$ ), 6.56 (1H, s, $\mathrm{H}_{\mathrm{b}}$ ), 6.41-6.42 (2H, overlapping, $\left.\mathrm{m}, \mathrm{H}_{1 \mathrm{~A}, 1 \mathrm{~B}}\right), 1.18\left(9 \mathrm{H}, \mathrm{s}, \mathrm{H}_{\mathrm{Bu}}^{t}\right) .{ }^{13} \mathrm{C} \mathrm{NMR}\left(126 \mathrm{MHz}, \mathrm{CD}_{2} \mathrm{Cl}_{2}\right.$,
$298 \mathrm{~K}):{ }^{13} \mathrm{C}$ NMR (126 MHz, $\left.\mathrm{CD}_{2} \mathrm{Cl}_{2}, 298 \mathrm{~K}\right): \delta 167.4\left(\mathrm{C}_{\mathrm{q}}\right), 167.1$ $\left(\mathrm{C}_{\mathrm{q}}\right), 165.6\left(\mathrm{C}_{\mathrm{q}}\right), 156.9\left(\mathrm{C}_{\mathrm{q}}\right), 156.1\left(\mathrm{C}_{\mathrm{q}}\right), 152.3\left(\mathrm{C}_{\mathrm{q}}\right), 151.0\left(\mathrm{C}_{8 \mathrm{~A}}\right)$, $149.8\left(\mathrm{C}_{\mathrm{q}}\right), 149.6\left(\mathrm{C}_{\mathrm{h}}\right), 149.5\left(\mathrm{C}_{8 \mathrm{~B}}\right), 149.3\left(\mathrm{C}_{\mathrm{q}}\right), 148.2\left(\mathrm{C}_{\mathrm{q}}\right), 138.5$ $\left(\mathrm{C}_{\mathrm{f} / \mathrm{e}}\right), 138.0\left(\mathrm{C}_{6 \mathrm{~A} / 6 \mathrm{~B}}\right), 137.6\left(\mathrm{C}_{6 \mathrm{~A} / 6 \mathrm{~B}}\right), 128.2\left(\mathrm{C}_{1 \mathrm{~A} / 1 \mathrm{~B}}\right), 128.1$ $\left(\mathrm{C}_{1 \mathrm{~A} / 1 \mathrm{~B}}\right), 124.7\left(\mathrm{C}_{4 \mathrm{~A} / 4 \mathrm{~B}}\right), 124.5\left(\mathrm{C}_{4 \mathrm{~A} / 4 \mathrm{~B}}\right), 124.4\left(\mathrm{C}_{7 \mathrm{~A} / 7 \mathrm{~B}}\right), 124.0$ $\left(\mathrm{C}_{7 \mathrm{~A} / 7 \mathrm{~B}}\right), 122.1\left(\mathrm{C}_{\mathrm{g}}\right), 120.6\left(\mathrm{C}_{5 \mathrm{~A} / 5 \mathrm{~B}}\right), 120.2\left(\mathrm{C}_{5 \mathrm{~A} / 5 \mathrm{~B}}\right), 119.9\left(\mathrm{C}_{\mathrm{f} / \mathrm{e}}\right)$, $119.3\left(\mathrm{C}_{3 \mathrm{~A}}\right), 118.4\left(\mathrm{C}_{3 \mathrm{~B}}\right), 100.5\left(\mathrm{C}_{\mathrm{b}}\right), 31.4\left(\mathrm{C}_{\mathrm{Bu}}^{t}\right)$. The $\mathrm{CCF}_{3}$ carbons were not observed. ${ }^{19} \mathrm{~F}$ NMR $\left(376 \mathrm{MHz}, \mathrm{CD}_{2} \mathrm{Cl}_{2}\right.$, $298 \mathrm{~K}): \delta-62.86(\mathrm{~s}),-62.91$ (s). HRMS (ESI): $[\mathrm{M}+\mathrm{H}]^{+} \mathrm{m} / \mathrm{z}$ 838.1959 [838.1956 calculated for $\mathrm{C}_{36} \mathrm{H}_{29} \mathrm{~F}_{6}{ }^{193} \mathrm{IrN}_{5}$ ].

\section{Conflicts of interest}

There are no conflicts to declare.

\section{Acknowledgements}

One of us (NSYA) is grateful to the Omar Al-Mukhtar University Tobruk Libya and the Libyan Embassy in the UK for financial support and to the Libya Ministry of Education Programme for a scholarship.

\section{Notes and references}

1 (a) C. Y. S. Chung, S. P. Y. Li, M. W. Louie, K. K. W. Lo and V. W. W. Yam, Chem. Sci., 2013, 4, 2453-2462; (b) B. Tang, X. Liu, K. Xu, H. Huang, G. Yang and L. An, Chem. Commun., 2007, 3726-3728; (c) H. R. Kermis, Y. Kostov, P. Harms and G. Rao, Biotechnol. Prog., 2002, 18, 10471053; (d) L. Cao, X. Li, S. Wang, S. Li, Y. Li and G. Yang, Chem. Commun., 2014, 50, 8787-8790; (e) M. Y. Wu, K. Li, Y. H. Liu, K. K. Yu, Y. M. Xie, X. D. Zhou and X. Q. Yu, Biomaterials, 2015, 53, 669-678; (f) Y. Ge, A. Liu, J. Dong, G. Duan, X. Cao and F. Li, Sens. Actuators, B, 2017, 247, 4652.

2 (a) K. Qiu, Y. Chen, T. W. Rees, L. Ji and H. Chao, Coord. Chem. Rev., 2019, 378, 66-86; (b) S. Das, D. Saha, S. Karmakar and S. Baitalik, J. Phys. Chem. A, 2012, 116, 5216-5226; (c) Q. Zhao, F. Li and C. Huang, Chem. Soc. Rev., 2010, 39, 3007-3030; (d) B. V. Harbuzaru, A. Corma, F. Rey, J. L. Jordá, D. Ananias, L. D. Carlos and J. Rocha, Angew. Chem., Int. Ed., 2009, 48, 6476-6479; (e) T.-T. Meng, H. Wang, Z.-B. Zheng and K.-Z. Wang, Inorg. Chem., 2017, 56, 4775-4779; $(f)$ V. W. W. Yam, V. K. M. Au and S. Y. L. Leung, Chem. Rev., 2015, 115, 7589-7728; (g) M. Bar, D. Maity, S. Deb, S. Das and S. Baitalik, Dalton Trans., 2017, 46, 12950-12963.

3 (a) J. N. Demas and B. A. DeGraff, Anal. Chem., 1991, 63, 829A-837A; (b) J. N. Demas and B. A. DeGraff, J. Chem. Educ., 1997, 74, 690-695.

4 (a) B. Higgins, B. A. DeGraff and J. N. Demas, Inorg. Chem., 2005, 44, 6662-6669; (b) H. J. Kim, Y.-C. Jeong, J. Heo, J. I. Rhee and K.-J. Hwang, Bull. Korean Chem. Soc., 2009, 30, 539-540; (c) S. San Tan, S. Yanagisawa, K. Inagaki, 
Y. Morikawa and M. B. Kassim, Phys. Chem. Chem. Phys., 2017, 19, 25734-25745; (d) H. J. Yu, Z. F. Hao, H. L. Peng, R. H. Rao, M. Sun, R. Alana, W. C. Ran, H. Chao and L. Yu, Sens. Actuators, B, 2017, 252, 313-321; (e) F. Yu, C. Shen, T. Zheng, W. K. Chu, J. Xiang, Y. Luo, C. C. Ko, Z. Q. Guo and T. C. Lau, Eur. J. Inorg. Chem., 2016, 2016, 3641-3648.

5 (a) T. Mizuno, T. Fukumatsu, M. Takeuchi and S. Shinkai, J. Chem. Soc., Perkin Trans. 1, 2000, 407-413; (b) M. H. W. Lam, D. Y. K. Lee, K. W. Man and C. S. W. Lau, J. Mater. Chem., 2000, 10, 1825-1828; (c) M. Cattaneo, F. Fagalde, C. D. Borsarelli and N. E. Katz, Inorg. Chem., 2009, 48, 3012-3017; (d) T. W. Tseng, S. Mendiratta, T. T. Luo, T. W. Chen and Y. P. Lee, Inorg. Chim. Acta, 2018, 477, 312-317.

6 (a) K. M. C. Wong, W. S. Tang, X. X. Lu, N. Zhu and V. W. W. Yam, Inorg. Chem., 2005, 44, 1492-1498; (b) J. L. L. Tsai, T. Zou, J. Liu, T. Chen, A. O. Y. Chan, C. Yang, C. N. Lok and C. M. Che, Chem. Sci., 2015, 6, 3823-3830.

7 M. Licini and J. A. G. Williams, Chem. Commun., 1999, 1943-1944.

8 (a) M. A. Baldo, S. Lamansky, P. E. Burrows, M. E. Thompson and S. R. Forrest, Appl. Phys. Lett., 1999, 75, 4-6; (b) M. K. Nazeeruddin, C. Klein, M. Grätzel, L. Zuppiroli and D. Berner, in Highly Efficient OLEDs with Phosphorescent Materials, Wiley-VCH Verlag GmbH \& Co. KGaA, 2008, pp. 363-390; (c) C. Ulbricht, B. Beyer, C. Friebe, A. Winter and U. S. Schubert, Adv. Mater., 2009, 21, 4418-4441; (d) E. Longhi and L. De Cola, in Iridium(III, ) in Optoelectronic and Photonics Applications, ed. E. Zysman-Colman, John Wiley \& Sons Ltd, 2017, pp. 205-274; (e) D. L. Ma, S. Lin, W. Wang, C. Yang and C. H. Leung, Chem. Sci., 2017, 8, 878-889; $(f)$ V. Fernandez-Moreira, F. L. Thorp-Greenwood and M. P. Coogan, Chem. Commun., 2010, 46, 186-202; $(g)$ E. Baggaley, J. A. Weinstein and J. A. G. Williams, Coord. Chem. Rev., 2012, 256, 1762-1785; (h) Q. Zhao, C. Huang and F. Li, Chem. Soc. Rev., 2011, 40, 2508-2524; ( $i$ ) K. K. S. Tso and K. K. W. Lo, in Iridium(III) in Optoelectronic and Photonics Applications, ed. E. ZysmanColman, John Wiley \& Sons Ltd, 2017, pp. 415-477.

9 A. Nakagawa, Y. Hisamatsu, S. Moromizato, M. Kohno and S. Aoki, Inorg. Chem., 2014, 53, 409-422.

10 A. Kando, Y. Hisamatsu, H. Ohwada, T. Itoh, S. Moromizato, M. Kohno and S. Aoki, Inorg. Chem., 2015, 54, 5342-5357.

11 J. Weng, Q. Mei, W. Jiang, Q. Fan, B. Tong, Q. Ling and W. Huang, Analyst, 2013, 138, 1689-1699.

12 K. Qiu, L. Ke, X. Zhang, Y. Liu, T. W. Rees, L. Ji, J. Diao and H. Chao, Chem. Commun., 2018, 54, 2421-2424.

13 M. Qian, Z. Wang, H. Qi and H. Qi, Inorg. Chem. Commun., 2019, 106, 95-98.

14 (a) D.-K. Cao, J.-S. Hu, M.-Q. Li, D.-P. Gong, X.-X. Li and M. D. Ward, Dalton Trans., 2015, 44, 21008-21015; (b) A. J. Hallett, B. D. Ward, B. M. Kariuki and S. J. A. Pope, J. Organomet. Chem., 2010, 695, 2401-2409; (c) A. F. Henwood, Y. Hu, M. T. Sajjad, G. K. V. V. Thalluri,
S. S. Ghosh, D. B. Cordes, A. M. Z. Slawin, I. D. W. Samuel, N. Robertson and E. Zysman-Colman, Chem. - Eur. J., 2015, 21, 19128-19135; (d) L. Murphy, A. Congreve, L. O. Palsson and J. A. G. Williams, Chem. Commun., 2010, 46, 87438745; (e) S. A. Rommel, D. Sorsche, N. Rockstroh, F. W. Heinemann, J. Kübel, M. Wächtler, B. Dietzek and S. Rau, Eur. J. Inorg. Chem., 2015, 2015, 3730-3739.

15 L. He, Y. Li, C. P. Tan, R. R. Ye, M. H. Chen, J. J. Cao, L. N. Ji and Z. W. Mao, Chem. Sci., 2015, 6, 5409-5418.

16 (a) C.-K. Koo, Y.-M. Ho, C.-F. Chow, M. H.-W. Lam, T.-C. Lau and W.-Y. Wong, Inorg. Chem., 2007, 46, 36033612; (b) C. K. Koo, K. L. Wong, C. W. Y. Man, Y. W. Lam, L. K. Y. So, H. L. Tam, S. W. Tsao, K. W. Cheah, K. C. Lau, Y. Y. Yang, J. C. Chen and M. H. W. Lam, Inorg. Chem., 2009, 48, 872-878; (c) C.-K. Koo, K.-L. Wong, C. W.-Y. Man, H.-L. Tam, S.-W. Tsao, K.-W. Cheah and M. H.-W. Lam, Inorg. Chem., 2009, 48, 7501-7503.

17 T. Y. Lin, K. C. Tang, S. H. Yang, J. Y. Shen, Y. M. Cheng, H. A. Pan, Y. Chi and P. T. Chou, J. Phys. Chem. A, 2012, 116, 4438-4444.

18 D. L. Davies, M. P. Lowe, K. S. Ryder, K. Singh and S. Singh, Dalton Trans., 2011, 40, 1028-1030.

19 N. M. Shavaleev, F. Monti, R. Scopelliti, N. Armaroli, M. Grätzel and M. K. Nazeeruddin, Organometallics, 2012, 31, 6288-6296.

20 P. J. Spellane, R. J. Watts and C. J. Curtis, Inorg. Chem., 1983, 22, 4060-4062.

21 (a) W. Jiang, Y. Gao, Y. Sun, F. Ding, Y. Xu, Z. Bian, F. Li, J. Bian and C. Huang, Inorg. Chem., 2010, 49, 3252-3260; (b) F. Neve, M. La Deda, A. Crispini, A. Bellusci, F. Puntoriero and S. Campagna, Organometallics, 2004, 23, 5856-5863; (c) E. Orselli, G. S. Kottas, A. E. Konradsson, P. Coppo, R. Fröhlich, L. De Cola, A. van Dijken, M. Büchel and H. Börner, Inorg. Chem., 2007, 46, 11082-11093; (d) Q. Zhao, S. Liu, M. Shi, C. Wang, M. Yu, L. Li, F. Li, T. Yi and C. Huang, Inorg. Chem., 2006, 45, 6152-6160.

22 (a) M. K. Nazeeruddin, R. T. Wegh, Z. Zhou, C. Klein, Q. Wang, F. De Angelis, S. Fantacci and M. Grätzel, Inorg. Chem., 2006, 45, 9245-9250; (b) M. S. Lowry, J. I. Goldsmith, J. D. Slinker, R. Rohl, R. A. Pascal, G. G. Malliaras and S. Bernhard, Chem. Mater., 2005, 17, 5712-5719.

23 We have called the $\mathrm{p} K_{\mathrm{a}}$ determined from the fluorescence titration the emission $\mathrm{p} K_{\mathrm{a}}$. The difference between this and the excited state $\mathrm{p} K_{\mathrm{a}}$ is explained in J. G. Vos, Polyhedron, 1992, 11, 2285-2299.

24 (a) W. S. Yu, C. C. Cheng, Y. M. Cheng, P. C. Wu, Y. H. Song, Y. Chi and P. T. Chou, J. Am. Chem. Soc., 2003, 125, 10800-10801; (b) X. Y. Yu, L. Deng, B. Zheng, B. R. Zeng, P. Yi and X. Xu, Dalton Trans., 2014, 43, 15241533.

25 M. Pichette Drapeau, T. Ollevier and M. Taillefer, Chem. Eur. J., 2014, 20, 5231-5236.

26 C. Liu, X. Lv, Y. Xing and J. Qiu, J. Mater. Chem. C, 2015, 3, 8010-8017. 